WORKING PAPER NO. 173

\title{
THE ROLE OF PRICE AND COST COMPETITIVENESS IN APPAREL EXPORTS, POST-MFA: A REVIEW
}

Meenu Tewari

NOVEMBER 2005

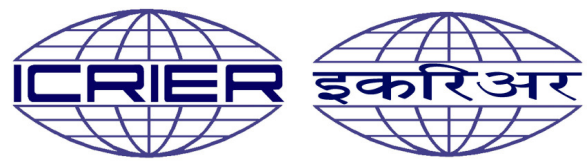

INDIAN COUNCIL FOR RESEARCH ON INTERNATIONAL ECONOMIC RELATIONS

Core-6A, 4th Floor, India Habitat Centre, Lodi Road, New Delhi-110 003

Website: www.icrier.org 


\section{THE ROLE OF PRICE AND COST COMPETITIVENESS IN APPAREL EXPORTS, POST-MFA: A REVIEW}

Meenu Tewari

NOVEMBER 2005

The views expressed in the ICRIER Working Paper Series are those of the author(s) and do not necessarily reflect those of the Indian Council for Research on International Economic Relations (ICRIER). 


\section{Table of Contents}

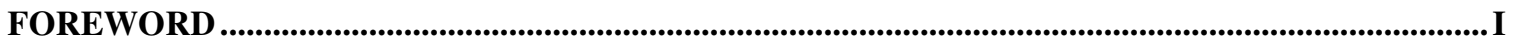

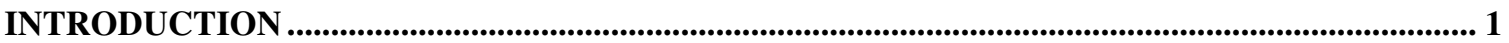

SECTION 1: WHAT THE STANDARD LITERATURE SAYS ABOUT THE EFFECT OF THE END OF QUOTAS ON GLOBAL APPAREL SUPPLIERS....................................................................... 4

SECTION 2: THE CHANGED CONDITIONS OF COMPETITION ................................................ 15

SECTION 3: THE OFF-SHORING OF PRODUCTION AND THE GLOBAL VALUE CHAIN

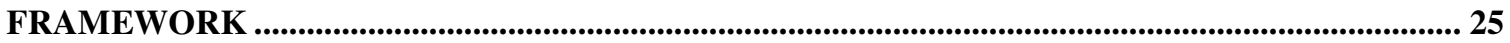

SECTION 4: LEAN RETAILING, AND SPECIALIZATION: THE RETURN OF PROXIMITY AS

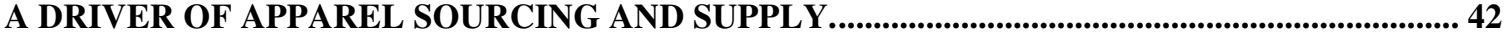

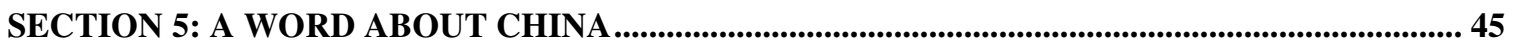

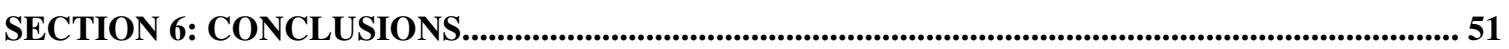

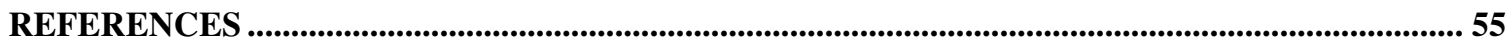

\section{$\underline{\text { List of Tables }}$}

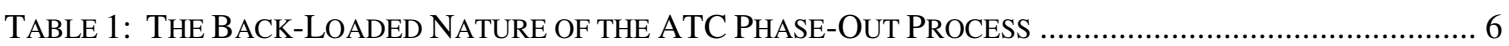

TABLE 2: PROJECTED IMPACT OF QUOTA REMOVAL ON THE EU AND US APPAREL MARKETS - CHANGING

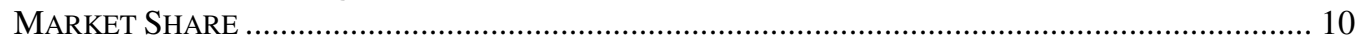

TABLE 3: COMPARISON OF ORGANIZATIONAL FORMS............................................................................ 23

TABLE 4: OUT-SOURCING AND OFF-SHORING OF LABOR-INTENSIVE WORK - LATE 1970S TO 1980S ........... 24

TABLE 5: Distribution OF Global VALUe AdDED IN TeXTILES AND APPAREL........................................ 31

\section{$\underline{\text { List of Figures }}$}

FiguRE 1: POST-MFA YeAR-TO-DATE GROWTH RATE OF APPAREL EXPORTS TO THE US FROM 35 TOP SUPPLIER COUNTRIES (PERCENT CHANGE IN EXPORTS): JANUARY-AUGUST 2005 OVER JANUARY-AUGUST 2004

Figure 2: COMPARISON OF THE Flow OF VALUE AdDED ACROSS THE INDIAN ClOthing VALUE Chain:

EVIDENCE FROM MEN'S COTTON SHIRTS AND TOURSERS ........................................................ 29

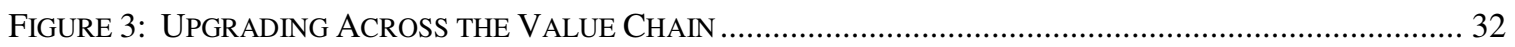

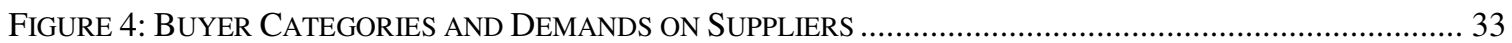

Figure 5: Rising to Full-PACKAGE IN MEXICO’s Blue JEANS IndUSTRY: TORREON IN 1993-2000....... 38 


\section{Foreword}

Global outsourcing, technical change, and falling barriers to trade worldwide have transformed the structure of production and global competition in the textile and apparel industry. This sector has experienced intense fragmentation in the last two decades. Much of this global dispersal was driven by the Multifibre Arrangement (MFA). The elimination of quotas on January 1, 2005 has triggered a restructuring of existing patterns of sourcing and supply. As buyers consolidate their sourcing strategies, and as smaller countries experience an erosion of apparel FDI post-MFA, many policy makers and companies are pointing to China's tremendous surge in apparel exports in the first months of quota removal to argue that price, unit costs, and volumes appear to be crucial determinants of export competitiveness in the world without quotas. This has led many firms to try to increase their scale of production in the hope of maintaining their place in the global division of labor in textiles and apparel.

This paper reviews a growing body of literature that focuses on the institutional organization of global trade networks and production chains. It shows that firms today face altered conditions of competition that are pushing them to compete on the basis of factors other than price and cost competitiveness. In an environment with fragmented demand and volatile markets buyers are increasingly demanding good quality, variety, and timely delivery in addition to price. Even the largest buyers (e.g., Walmart) require their suppliers to replenish their stocks rapidly - e.g., weekly and in short cycles. Under these conditions large scales of operation can add to costs unless they are embedded within other capabilities of timely supply and low inventories that the environment demands.

The paper also argues that the attribution of China's remarkable export performance in textiles and apparel to its low unit costs and large scales of production is, in part, a misreading of the China story. China's costs are low, and its production scales enormous, but they are embedded within crucial abilities that lower the "costs" of large scales of operation (i.e., of rigidity) in the context of uncertain markets. China's low cost producers are deeply embedded within the marketing, distribution and supply management networks of locally rooted Hong Kong, Taiwanese and South Korean 'triangle manufacturers' who understand global markets well and have a long history of doing business with the most demanding of industrial markets, and who have mastered the capability to manage diversified production networks to deliver a wide range of quality products to its buyers in a timely way. These factors make China much more than a mere low-cost producer apparel exporter.

The end of quotas, and the ongoing churning in the global division of labor in apparel and textiles can be an opportunity for apparel producing firms in India with their severe handicap arising from labour policy induced rigidities, to chart an alternative growth path. This paper provides a view of this alternative.

Arvind Virmani

Director \& Chief Executive

ICRIER

November 2005 


\section{Introduction}

The Multi Fibre Arrangement (MFA) and the system of bilateral quotas that has governed the global trade in textiles and apparel for the past forty years came to an end on January 1, 2005. While the removal of global textile quotas has eliminated one of the most significant pieces of international trade protection in a half century (Levinsohn and Petropolous 2001), ${ }^{1}$ it has simultaneously unleashed a fierce debate about the continued competitiveness of various supplier countries and their place in the international division of labor in textiles and apparel. Over the past forty years the system of quotas contributed to the dispersal of the apparel industry across scores of countries. ${ }^{2}$ For example, in 1992, nearly half (49 percent) of all retail apparel sold in the United States was made in the US, but by 1999, just seven years later, the proportion of domestically produced retail apparel had fallen to 12 percent (Rabon 2001 cf. UNIDO Report 2003:7). By 2003, developing countries accounted for nearly three quarters of the export flows in apparel which constituted more that half $(57 \%)$ of the $\$ 408$ billion in global textile and apparel trade that year. Many of these supplier countries today depend crucially on their apparel export sectors for foreign exchange, employment and national income. For example, clothing exports constitute $74 \%, 94 \%$ and $64 \%$ of total merchandise exports in Bangladesh, Lesotho ${ }^{3}$ and El Salvador respectively (WTO 2001, US ITC 2004) ${ }^{4}$ and the apparel and textile sectors are the largest industrial employers in each country.

\footnotetext{
${ }^{1}$ Textiles and clothing is now fully integrated into the General Agreement on Tariffs and Trade (GATT) of the World Trade Organization (WTO) - as January 1.2005, and on paper, only a system of national tariffs and a narrow set of safeguard measures restrict trade; subject to these constraints, suppliers are free to export as much product as they are able (Weil 2004, UNCTAD 2005).

${ }^{2}$ When textile and apparel quotas became binding in one country, buyers opened up production centers in new unconstrained sites where quotas were available, moving on to other locations once again when quotas there got exhausted.

${ }^{3}$ The rapid rise of apparel exports from Africa in the last four years is a result in large part of AGOA - the African Growth and Opportunity Act - that the US signed with 37 African countries in 2000. These countries are allowed tariff and quota free entry into the US clothing market in return for progress along several dimensions - a move toward market-based economies, rule of law, elimination of barriers to US trade and investment, protection of intellectual property, policies to reduce poverty, increase the availability of health-care, education and the protection of human rights and worker rights (www.agoa.com, cf. Appelbaum et. al, 2005)

${ }^{4}$ US International Trade Commission, 2004, op cit, Table 1-1, p. 1-4
} 
With the elimination of global textile quotas, and buyers free to source any amount of apparel from any country (subject only to a system of tariffs and safeguard measures), the geography of apparel production and trade is in tremendous flux (Gereffi 2004, Appelbaum 2005, UNCTAD 2005, USTIC 2004, WTO 2004). The dominant assumption is that with the removal of quotas, large, low-wage countries in Asia (such as China and India), with their stable supply networks and large production capacities will benefit from the reorganization of global trade rules, while many smaller countries that had benefited from quota protection and assured market access under the MFA, will lose out. Firms and policy makers point to the price deflation already experienced by apparel suppliers after the removal of quotas in January 2005, and to the growing consolidation among global buyers and retailers, as well as the early tide of withdrawal of foreign direct investment in textiles and apparel from many small countries (such as Mauritius, Lesotho and Madagascar among others) to argue that the end of quotas is already shaping winners and losers, and adjustment is likely to be complex, uncertain, and for many, painful, in the short-run.

As countries search for ways to compete in this volatile environment, a widespread assumption seems to be that with the removal of quotas, price, unit costs and volumes are likely to become even more critical determinants of global competitiveness for apparel and textile producers than previously. Policy makers and companies are pointing to China's explosive apparel export growth (of several hundred percent in some categories) in the months following the removal of quotas to conclude, or at least fear, that there are few alternatives to matching China's massive volumes and low prices. In many countries industry analysts are thus advising governments and firms to substantially ramp up their capacities and scales of operation and relentlessly lower costs. For example, in countries where labor laws are relatively 'inflexible' (in ways that inhibit scaling up), scholars, industry analysts and politicians have called for the need to dismantle several labor protections to allow local industry to scale up in order to compete with China. But, is scaling up and cutting costs enough to compete successfully in today's international markets? Is that all that lies behind China's export success? This review examines a growing body of literature that links international trade with the 
institutional organization of that trade and production to argue that there are several additional factors - beyond the traditional factors of relative prices, exchange rates, transportation costs, tariffs and customs costs ${ }^{5}$-- that are at play in shaping the structure of sourcing and supply in the apparel and textile industry today (Abernathy et. al. 1999, 2004, Gereffi 1994, 1999, 2001, Gereffi et. al. 2004, Sabel 1994, Sabel and Reddy 2002, Piore 2002, Feenstra 1998, Dicken 1990, Schott 2004, Evans and Harrigan 2005, Tendler 2001). In portraying a different, more complex view of international sourcing, supply and competitiveness, this literature has important implications for policy as well as for our understanding of the conditions under which suppliers can compete and grow in today's trade liberalized, post-quota world.

The paper is organized as follows: The next section briefly describes the institutional context within which textile and apparel trade took place over the last forty years. After a brief review of the MFA and ATC regimes, I briefly review what some of the most commonly cited quantitative models say about the elimination of quotas. Section two examines the altered conditions of competition in product and international markets. The next section examines three frameworks that have gained currency among scholars in recent years in analyzing how firms compete in today's volatile markets. These are: the flexible production networks literature, the outsourcing and global commodity chain (or global value chain) literature, and the 'lean retailing' and specialization literature. The fourth section explores the issue of upgrading, especially in Mexico and China. It looks at what firms are actually doing and how the various frameworks' discussed in section three speak to this experience in terms of policy. The final section concludes.

\footnotetext{
${ }^{5}$ See Abernathy, Volpe and Weil (2004)
} 


\section{Section 1: What the standard literature says about the effect of the end of quotas on global apparel suppliers.}

The MFA, the ATC, and the back-loaded character of its dismantling

The institutional context within which textile and apparel trade has taken place over the past forty years was characterized, till recently, by deep protectionism. The Multifibre Arrangement (MFA), and its successor, the Agreement of Textiles and Clothing (ATC) which governed trade in textiles till it was abolished in January 2005, represented an elaborate system of protections (discriminatory bilateral quotas) that regulated the access of developing country apparel suppliers to key industrial markets in the US, EC, Canada, Norway and Australia. The origins of the MFA lie in the Voluntary Export Restraint (VER) agreement that the United States negotiated with Japan in 1957 to control cotton textile imports into the US (Krishna and Tan 1998). While the VER managed to curb cotton textile imports from Japan, many new exporters, such as Hong Kong, Portugal, Egypt and India, soon emerged on the scene (see Krishna and Tan 1998 for a detailed history). In an attempt to apply VER-like restraints to a wider set of exporters, the US, along with the EC, turned to the multilateral GATT framework for global discussions on the import of cotton textile into their countries. This led to a series of agreements - e.g., the Short Term Agreement on Cotton and Textiles in 1961, followed by the Long Term Agreement on Cotton and Textiles, all of which culminated in 1974 in a more general framework of import restraints governed by WTO under the rules of the Multifibre Arrangement (MFA). The MFA defining framework governing the global trade in textiles and apparel for the next twenty years.

The MFA gave rise to a costly and complicated administrative structure - in buyer and supplier countries - for allocating apparel and textile quotas to hundreds of suppliers in developing countries, for the production of hundreds of apparel categories that could be traded, and monitoring their use. As a large literature reports, the quota system generated extensive rent-seeking and distortions within exporting countries and between buyers and suppliers as quota recipients bid up quota rents, raising the cost of apparel for industrial country buyers while enriching some exporters - mainly quota 
recipients - at the expense of others. ${ }^{6}$ At the same time, the MFA also led to the dispersal of apparel assembly and production to scores of countries around the world. At its peak, seventy-three supplier countries participated in the textile quota system under the MFA, with different levels of quotas allocated to each (Krishna and Tan 1998). An additional twenty-nine countries participated in voluntary capacity adhering to unilateral, non-MFA restraints (Abernathy et. al. 2004, OECD 2003). Eventually, in 1995, member countries of the WTO agreed to transition away from the complexity of the quota system. The abolition of quotas was to occur over a ten year period under the Agreement on Textiles and Clothing (ATC). After considerable uncertainty, and following a highly complicated transition process, all quotas were finally phased out on January 1, 2005.

Ever since the Agreement in Textile and Clothing was signed in 1995, and leading up to the dissolution of quotas, much has been written about the anticipated effects of the phase-out of the bilateral quota system on suppliers in various countries.

First, nearly all accounts of the ATC phase-out highlight the back-loaded character of the implementation of the ATC. As Table 1 shows, nearly half (49 percent) of all constrained items became integrated only at the very end of the ten year transition period of the quota phase-out, on January 1, 2005. In some product categories the amount withheld till the end was as high as 86 percent (Chatterjee 2005, see also Abernathy et. al. 2004). Most importing countries moreover were strategic in how they sequenced their integration into the ATC - taking care to liberalize their lowest value products first, such as yarn and textiles, and protecting till the end their most important value-added product categories (Abernathy et. al 2004).

\footnotetext{
6 See: Trela and Whalley 1995, Krishna, Erzan and Tan 1994, Krishna and Tan 1998, Kathuria and Bhardwaj 1998, Harrison, Rutherford and Tarr 1997 among others. As some studies reported, exporting firms often had to share their quota rents with importers (Krishna, Erzan and Tan 1994). Moreover the effect of quotas varied by country depending upon fill-rates and how constrained the country was. Those who did not "fill" the allocated quotas enjoyed protection under the quota system in contrast to those who reached their quota limits quickly.
} 
Table 1: The Back-Loaded Nature of the ATC Phase-Out Process

\begin{tabular}{|c|c|c|c|c|}
\hline Phases & Date & 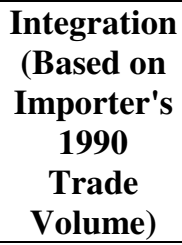 & $\begin{array}{c}\text { Cumulative } \\
\text { Percentage } \\
\text { of Trade } \\
\text { Integrated }\end{array}$ & $\begin{array}{c}\text { Growth Rate } \\
\text { of Residual } \\
\text { Quotas* }\end{array}$ \\
\hline Phase I & Jan. 11995 & $16 \%$ & $16 \%$ & $16 \%$ \\
\hline Phase II & Jan 11998 & $17 \%$ & $33 \%$ & $25 \%$ \\
\hline Phase III & Jan 12001 & $18 \%$ & $51 \%$ & $27 \%$ \\
\hline Final Phase & Jan 12005 & $49 \%$ & $100 \%$ & No Quotas \\
\hline
\end{tabular}

* Growth relative to initial, pre-agreed rates (E.g., $3 \%-3.5 \%$ in Phase I in

Phase II, the growth rate would be a $25 \%$ increase in the $3.5 \%$ rate)

Source: Word Trade Organization

The back-loaded implementation of the ATC had two implications for importing and supplying countries. For industrial countries the result of delayed adjustment was a sharper, more intense dislocation after the dismantling of protections; and for supplier countries the main effect was price-pressure and uncertainty. By saving till the end the integration of their most vital product categories, industrial countries have ended up subjecting their apparel producers and workers to a harsher and more concentrated impact of the simultaneous loss of protections across a range of their most important product segments. ${ }^{7}$ The ensuing dislocation - as witnessed already by the massive layoffs in the apparel sector in the US and EU - has led to escalated political tensions (between the US, EU and China for example), to vocal concerns in the popular press against cheap imports and the demand by apparel associations and manufacturing communities for the invoking of safeguard measures (against China, most notably) and the return to some degree of protection (see Appelbaum et. al. 2005).

\footnotetext{
${ }^{7}$ With the real effects of liberalized trade not likely to be till 2005, Reinert (1993) estimates that the US will lose 16,100 jobs in the textiles sector and 21,300 full-time jobs in the clothing sectors post-MFA. Disaggregating households into eleven income categories, Hanson and Reinert (1997) further find that these job losses fall disproportionately on low-income workers. Benefits to consumers from lower import prices (of apparel) do not off-set the difficulty of adjustment in finding alternative employment. The working families affected by lay-offs in the US textiles and apparel industry are thus expected to be worse off than they were before quotas were abolished (OECD 2003). In genera;, post MFA adjustments are likely to be painful for many industrial country producers and communities, at least in the short run.
} 
For exporting (producing) countries, the major effect of a back-loaded integration process under the ATC has been its impact on price. The sudden freeing-up of a substantial number of constrained categories has put intense pressure on product prices, as suppliers compete for quota-free market share and as retailers demand -and obtain substantial price cuts now that quota-costs no longer apply. Past evidence from earlier rounds of liberalization (in the second and third phases of the ATC) shows that prices fell by nearly 10-20 percent in key product categories within a year of their liberalization (Gereffi and Memdovic, 2004, Knappe 2003, Singhal et. al 2004). In interviews in India just after the removal of quotas in 2005, many producers, especially (cut-make) contract manufacturers reported a significant fall in prices - 10-12\% in their post-MFA sourcing cycle (Interviews in Bangalore, Tiruppur 2005). Though not unforeseen, this squeeze on prices, in combination with trade tensions, the different levels of tariffs that still apply (differentially on different supplier countries) and unpredictable changes in the general system of preferences applied by different buyer countries to their various suppliers, has created tremendous uncertainty among suppliers, especially smaller sized suppliers about the process of adjustment and the anticipated gains and losses from the removal of quotas.

The standard predictions of studies on post-quota competitiveness ${ }^{8}$

Most quantitative studies that measure the projected effects of quota removal converge on the view that there will be global gains, in the aggregate, of quota removal for all countries taken together (ranging from $\$ 6$ billion world-wide annually in some studies to $\$ 324$ billion in others). ${ }^{9}$ But these gains are likely to come from different sources for importing and supplying countries. In industrial countries consumers gain from lower import prices, ${ }^{10}$ and improved terms of trade (export to import price ratios), while textile and apparel producers and workers lose out - losing market share as well as

\footnotetext{
${ }^{8}$ For a fuller review of the quantitative studies that model the effects of textile quota removal see: US ITC 2004, OECD 20003 and Nordad (WTO) 2004.

${ }^{9}$ Most studies estimate that the removal of restrictions under the MFA will increase textile and apparel trade by anywhere from $5 \%$ to $14 \%$ overall - with trade in apparel growing faster than trade in textiles (in some estimates twice as fast - Diao and Somwaru 2001).

${ }^{10}$ Cline 1987 (cf. OECD).
} 
manufacturing jobs to lower cost developing countries ${ }^{11}$ Conversely, firms in industrializing (exporting) countries are likely to gain from expanded market access, ${ }^{12}$ a shift toward more efficient scales and system of production, ${ }^{13}$ induced technological change, ${ }^{14}$ and the elimination of quota-related administrative costs. ${ }^{15}$ But not all supplier countries are estimated to gain equally. Most studies project that "efficient producers," such as China, South Asia, Indonesia, Thailand, and Malaysia would likely break into formerly restricted US and EU markets more easily than higher cost producers in Latin America, Middle East, North Africa, Eastern Europe and the former CIS countries, gaining market share at the expense of the latter (Harrison, Rutherford and Tarr 1997). Nearly all studies predict that China will be the major beneficiary of the liberalization of quotas - some estimating an astonishing increase in apparel production of $249 \%$ after quota removal and China's WTO accession, and a $330 \%$ increase in exports (Ianchovichina, Martin and Fukase 2000 cf.. OECD 2003).

The standard estimates of the projected gains and losses from quota removal are generally based on models that look at mainly three metrics of competitiveness (i) Relative prices, (ii) cost-competitiveness (based on cost functions that decompose production costs into broad components - capital, materials, labor, energy); (iii) and the relative level of a country's pre-abolition quota restrictiveness (i.e. the relative difference between quota caps and the supplier country's estimated comparative advantage in textiles). ${ }^{16}$ These variables are moreover measured using base-line data for particular years - 1993, 1996, 1998, with the assumption that trade patterns that prevailed during these years continue to prevail in subsequent years-a problematic assumption in itself,

\footnotetext{
${ }^{11}$ Yang, Martin and Yanagishima 1997 (cf. OECD 2003).

${ }^{12}$ Nearly all studies predict this outcome for developing countries as a whole, though individual countries fare quite differently.

${ }^{13}$ Trela and Whalley 1995 (cf. OECD).

${ }^{14}$ Bagch 1994 (cf. OECD).

${ }^{15}$ Krishna and Tan 1998, Diao and Somawaru 2001, Kathhuria and Bhardwaj 1998 (OCED 2003).

${ }^{16}$ The degree of restrictiveness of a quota is usually measured in terms of (1) the cost of acquiring and deploying a quota or its 'export tax equivalent' (ETE) (USITC 2004, Kathuria, Martin and Bhardwaj 2001, Krishna and Tan (1998), and (2) the degree to which the quota was 'binding' for a country's exports. The 'binding-ness' of a quota is measured by the degree of 'fill' of a quota or its utilization rate (i.e., ratio of a country's actual exports in an item to its total quota allocation in that item). The more restrictive the quota, the higher its cost or 'export tax.' The more binding the quota (i.e., the higher its utilization rate), the greater the degree of restrictiveness of the country's quota exports, and hence the greater its predicted post-quota export bounce.
} 
as we see below. Based on these measures, the assumption is that the lower a country's factor costs (given its endowments); and the greater its cost efficiency relative to its comparators, and the greater its pre-abolition restrictiveness of quotas, the greater will be its post-2005 boom in apparel exports. ${ }^{17}$ The familiar predictions thus follow: major gains in apparel export shares for China, to a smaller extent India, Indonesia and Thailand, and a net loss for several higher wage Latin American countries as well as Africa. $^{18}$

The most widely cited study in this regard (and amongst the most careful) is by Nordås of the WTO (2004) which estimates that China will gain 50 percent of the US market share in apparel after MFA, up more than 212 percent from its current share of 16 percent. India would increase its market share in the US five-fold from the current 3 percent to 15 percent after MFA. Similarly, China would gain 29 percent of the EU market after the removal of quotas (up from the current 18 percent), and India would improve its share in the EU from the current 6 percent to 9 percent post-MFA. Nordås' model also predicts marginal gains for Bangladesh in the EU, but predicts losses of market share in the US and EU of several of their traditional, more proximate suppliers such as Turkey and Central and Eastern Europe for the EU; and Mexico, Central America and the Caribbean for the US.

\footnotetext{
${ }^{17}$ I.e., one would expect countries like China and India which were the most quota-restrained suppliers to gain market share, say in the US relative to non-quota countries like Mexico etc whose biggest gains had already occurred pre-quota abolition and post-integration via NAFTA. In the long run prices and costefficiency drive market share in this view.

${ }^{18}$ As some have pointed out, the relatively slow growth of non-quota countries such as Latin America and Africa post-MFA is in part a correction of their earlier spurt in growth after the signing of quota-free regional trade agreements such as NAFTA and AGOA (E.g., Virmani).
} 
Table 2: Projected Impact of Quota Removal on the EU and US Apparel Markets - Changing Market Share

\begin{tabular}{|c|c|c|c|c|c|}
\hline EU & & & US & & \\
\hline & Before & After ATC & & Before & After ATC \\
\hline China & 18 & 29 & China & 16 & 50 \\
\hline India & 6 & 9 & India & 4 & 15 \\
\hline Turkey & 9 & 6 & Hong Kong & 9 & 6 \\
\hline Central and Eastern Europe & 9 & 6 & Rest of the Americas & 16 & 5 \\
\hline Hong Kong & 6 & 6 & Mexico & 10 & 3 \\
\hline Other north Africa & 6 & 5 & Thailand & & 3 \\
\hline Morocco & 5 & 4 & Philippines & 4 & 2 \\
\hline Poland & 5 & 4 & Indonesia & 4 & 2 \\
\hline Bangladesh & 3 & 4 & Bangladesh & 4 & 2 \\
\hline Indonesia & 3 & 3 & Sri Lanka & & 2 \\
\hline \multirow[t]{3}{*}{ Rest of the World } & 30 & 24 & Rest of the World & 24 & 10 \\
\hline & & & European Union & 5 & \\
\hline & & & Chinese Taipei & 4 & \\
\hline
\end{tabular}

Source: Nordås 2004 (WTO)

Based strictly on the logic of these (aggregate) models it would appear, as one analyst noted that "with the phasing out of quotas one of the most important determinant of exports [is] the cost competitiveness of the exporting country."19 Indeed, several recent studies have made precisely this argument calling for cost-reductions as a critical prerequisite for competing with more efficient apparel and textile producers such as China. In the Indian context, for example, the Gherzi Report (2003) argued that reducing the cost of inputs, energy, dyes, and chemicals - apart from the cost of wages, capital and technology - would be critical for India to take advantage of the elimination of quotas. Similarly, in a recent study Hashim (2005) undertook a detailed deconstruction of the cost-composition of Indian textile and garment exports, and of the sources of productivity in these sectors on a similar assumption that reducing unit costs, increasing the scale of production, and improving productivity are necessary and sufficient conditions for countries like India to remain competitive post-MFA. Using more aggregate models Elbehri, Hertel and Martin (2003) similarly argued that if the labor productivity of Indian textiles and apparel industries could be increased by 67

${ }^{19}$ Cited by an anonymous reviewer, 2005. 
percent to match China's, then the benefits to India of quota elimination would more than double (cf. OECD 2003).

However, while cost reductions in all the ways that Gherzi (2003), Hashim (2005) point out are important, and although the models on which these as well as other crosscountry projections of post-quota gains and losses are based have captured wide popular attention, they tell only a partial story. As the authors of the models themselves point out (Nordås 2004, OECD 2003, USITC 2004), they do not capture some of the fundamental ways in which the structure of apparel production, sourcing and trade have changed in recent years. They leave out of the analysis, for example, the powerful role that global retailers play today in shaping the geography of apparel production through their sourcing decisions and the organization of complex global clothing chains that span the globe; nor do they capture the growing importance of timeliness in apparel sourcing and supply, of flexibility, product diversity, inventory risk and the demand for rapid replenishment and other characteristics of lean retailing (see Abernathy et. al 1999, 2004), or the tremendous variation within countries, regions, production networks and supply chains. As Nordås (2004:5) puts it, these changes in the sourcing and trade of apparel have shifted "the question of competitiveness from mainly a question of production costs, to becoming a question of costs in combination with lead time, flexibility," and other factors such as quality, consistency, quick turnaround times and timely delivery privileged by the "new competition' (Best, 1990).

Moreover, as numerous disaggregated (qualitative as well as quantitative) studies of firms, plants and regions within countries have shown, it is misleading to base policy advice solely on aggregate industry or country level trends since they mask important dynamics that are playing out at the local level. For example, in a classic study of the US textile and apparel industry Levinsohn and Petropolous (2001) show that while aggregate industry level data shows that the US textile and apparel industry is in secular decline (and has been for the past half century), plant-level analysis shows a very different picture. It shows how firms are both entering as well as leaving this industry, that there is considerable technical change and innovation at the plant level, that even as jobs are 
being lost, many good, well-paying jobs are being simultaneously created. In other words, there is evidence of 'creative destruction' in this mature industry, and not just destruction or plain secular decline (Levinsohn and Petropolous 2001). The implications of this kind of analysis for policy is that it gives policy makers concrete clues about what to do: rather than merely viewing the textile industry as a dying, sunset industry that high-wage regions should transition away from, policy makers can help deepen the 'creative' part of the process of change by helping the industry as it transforms into a more flexible, innovative, higher tech, better paying, albeit leaner sector. ${ }^{20}$ In the US, the government has contributed to such efforts by encouraging, for example, innovation and $\mathrm{R} \& \mathrm{D}$ in the textile and apparel sector. The American Textile Partnership - a collaborative R\&D initiative between industry, professional associations and the government's national laboratories under the Department of Energy is an example of such an effort (Berger et. al. 1997). A byproduct of this collaboration is the National Sourcing Database, an extensive base of marketing, design and production information that US apparel and textile firms have used heavily to supply as well as source apparel since in the last decade (Berger, Karty and Gartner 1997).

Second, as is already well known, many of the assumptions that the cross-country models are based on do not - or need not - hold. For example, most studies assume that trade patterns which prevailed when the studies were conducted would continue to prevail after quotas are removed. This need not be the case. As we are already witnessing, the initial patterns of trade after the phase out of the MFA have brought some surprises. Most studies had predicted a sharp fall in apparel exports from small countries, such as Bangladesh, Cambodia and non-quota countries like Peru and Colombia, as they lost market share to lower cost China, but the opposite has been true. After a brief fall in the year to date growth rates, exports have grown from all these countries.

\footnotetext{
${ }^{20}$ Similarly, as Berger, Gartner and Karty show, even as late as in the 1990s, the US textile industry ranked among the top four industries in the country in terms of employment (employing 12\% of the workforce in 1992), sales, productivity increases in recent years and in contribution to manufacturing GDP (Berger and Lester 1997:140).
} 
Figure 1: Post-MFA Year-to-Date Growth Rate of Apparel Exports to the US from 35 Top Supplier Countries (Percent Change in Exports): January-August 2005 over January-August 2004

YTD Jan-August 2005 - Growth rate of apparel exports to the US

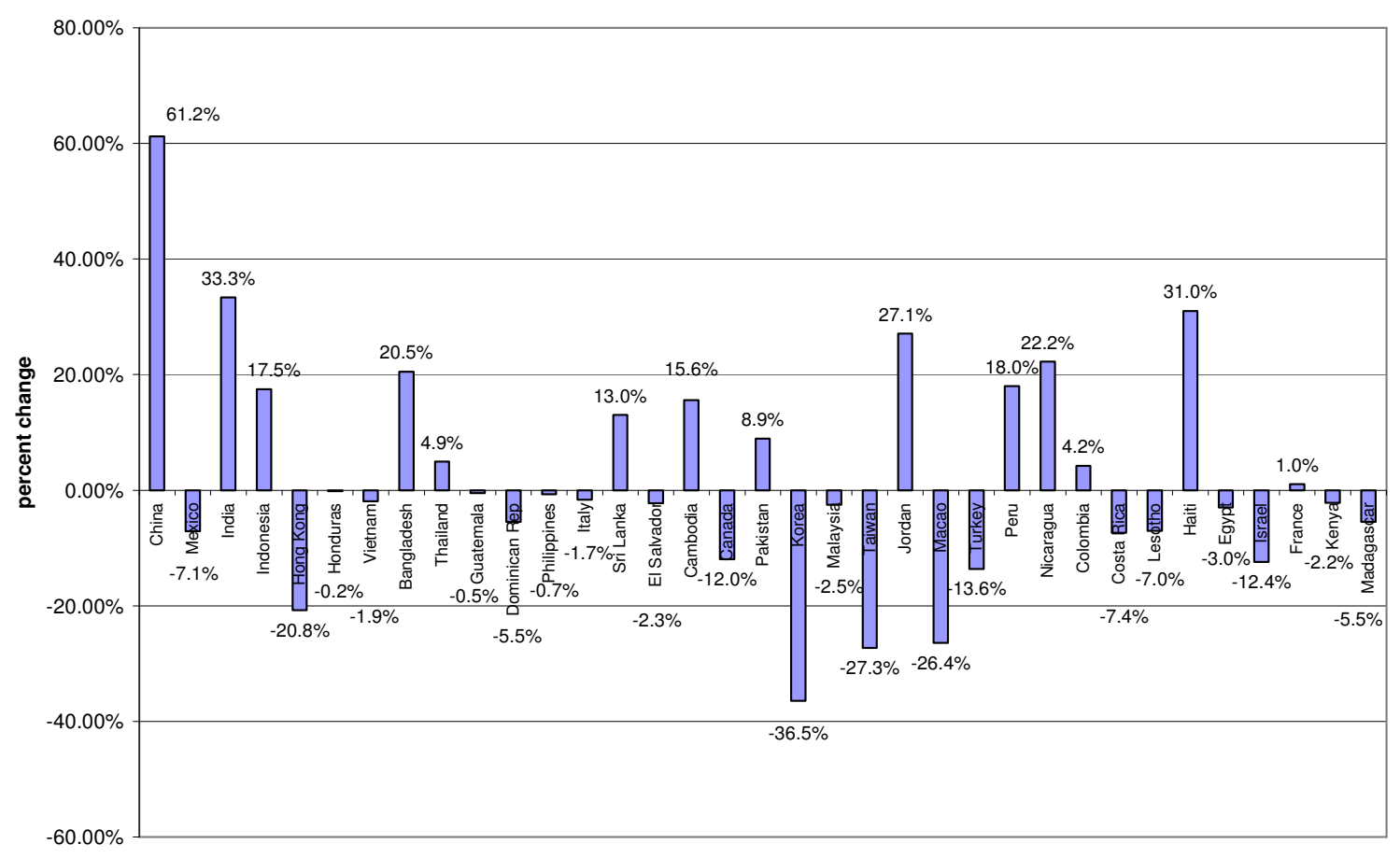

Source: Calculations are based on data from USITC, 2005

The elimination of quotas does not mean, then, that export shares of supplier countries or firms will now be determined largely through a play of market forces. Indeed, the continued importance of tariffs and preferential trade agreements - and their use as policy levers by buyer countries to reward or exclude supplier countries in the absence of quotas - illustrates quite well how the elimination of quotas does not automatically translate into unfettered market access for cost-competitive suppliers. Abernathy et. al. (2004) show, for example, how Bangladesh dominates the European market for T-shirts, but not the US market. Despite the same average cost of production Bangladeshi T-shirts fare differently in these two markets because of differential tariff levels, Abernathy et. al argue because of differential tariff levels. Based on its Lead Developed Country status, Bangladesh enjoys tariff-free entry into the EU for all apparel that undergoes two stages of production within the country (e.g, knitting and sewing), but this is not the case in the US. The US, instead gives tariff-free entry to Mexico, the 
Caribbean basin countries, Central America and a set of thirty seven African nations under AGOA with whom it has preferential trade agreements.

The rise of regional trade agreements (RTAs), such as NAFTA, CAFTA and AGOA similarly segments market access and create stickiness in trade by giving member countries preferential and duty-free access (based on rules of origin) to major markets in the US and EU, thus privileging them over others. To the extent that differential tariff levels become even more important after the end of quotas, participation in RTAs could off-set some of the losses that non-quota countries might have experienced vis-à-vis quota constrained Asian countries after the removal of quotas. Similarly, the reimposition of quotas and safeguard measures on China by the US and EU are further illustrations of how government policies and regulations (including international standards, codes of conduct, legal rights and domestic rules) continue to shape production and export outcomes in textiles and apparel world-wide, despite the removal of ATC regulations.

As a growing body of work has pointed out, fundamental changes in the nature of demand and of product markets, both of which have become more unstable, fragmented and volatile in the last two decades, have forced firms to deal with ever shortening product cycles and continuous demands for flexibility, quality and timeliness—over and above, price. Similarly dramatic changes in technology, the rise of outsourcing, and the diffusion of new kinds of work-practices such as flexible production, lean manufacturing and lean retailing have altered buyer-supplier relations and transformed the production networks and global supply chains within which industrial work, especially in footloose sectors such as textiles and apparel is organized-both locally and off-shore. All of these factors complicate adjustment and upgrading among producers as they try to deal with intensified competition in the global market for textiles and apparel. Thus, cost competitiveness while important, is only one component of any firm or region's attempt to improve its position in the global market place post-MFA. Equally critical is for firms and for policy-makers to take account of the ways in which numerous organizational forces are altering the structure of sourcing and supply today - over and above 
considerations of relative prices. It is to a review of these forces, and the literature that studies them, that we turn next.

\section{Section 2: The Changed Conditions of Competition}

It is by now widely accepted that the system of 'fordist' mass production that prevailed as the dominant form of industrial organization throughout the post-war period has broken down. In this system, which relied on stable demand for relatively standardized goods, long product cycles, and a detailed division of labor that facilitated the development of highly specialized technology embodied in dedicated equipment and progressive automation, static and dynamic scale economies were achieved through vertical integration and high volume production. Sophisticated management techniques (and demand growth) ensured high rates of capacity utilization that helped improve throughput, fuel productivity growth and lower unit costs. These cumulative gains fuelled a virtuous cycle of productivity-led growth. (Chandler 1977, Piore and Sabel 1984, Appelbaum and Batt 1994). Starting in the mid-1970s, the large stable markets that mass-production was predicated on began to break down.

The crisis of mass production was triggered by the convergence of three subsidiary crises in the 1979s: (1) the crisis of markets (and demand), (2) the crisis of competition, and (3) technical change (Piore and Sabel 1984, Feenstra 1998).

Triggered by the oil crises of the 1970s, with sharply rising energy prices and uncertainty about prices and availability of inputs, markets became characterized by tremendous flux and uncertainty in the 1970s and 1980s - an uncertainty that went beyond, and lasted well beyond the standard business cycle. This uncertainty in supply was compounded by fluctuation in the composition of demand, initially triggered by recessionary conditions of the 1970s and 1980s, but later by changes in consumer tastes as a growing middle class demanded product variety and good quality in addition to low price. Shifts in the international exchange rate mechanism - the switch from fixed to floating exchange rates in the 1970 s - the debt crisis in developing countries, structural 
adjustment and tight fiscal policies further heightened competition and uncertainty, leading to rising interest rates, volatility of demand, and high production costs. Thus, in both developed and developing countries, the crisis of supply, turned into a crisis of demand leading to a growing malaise of the large, rigid, integrated enterprises that found it difficult to respond quickly to the prevailing uncertainty, volatility and fragmentation of demand, and their own growing excess capacity (Piore and Sabel 1984).

Meanwhile, the rise of Japan and the Newly Industrializing Countries of East Asia (South Korea, Taiwan, Singapore and Hong Kong) as major exporters and global players in the late 1970s and 1980s led to a further intensification of competition worldwide. The strong promotion of export oriented industrialization in the late 1980s and 1990s by multilateral lending organizations (following structural adjustment policies) and national governments, as well as the integration of the former Soviet bloc and China into the global market, meant that a growing number of exporters were competing for the same products (labor-intensive, as well as low-and mid-tech goods and services) in the same, increasingly fragmented markets. Growing consumer demand for product variety, and the pressure on producers to differentiate their products and/or introduce new ones to capture market share, led to the dramatic shortening of product cycles since the 1980s (Piore and Sabel 1984, Best 1990). For example, there used to be two to four buying seasons in the international apparel industry, today there are six to eight if not more. New automotive models were introduced once every few years - today new models are introduced annually.

Simultaneously, rapid technical change, particularly the development of microprocessor-based technologies, aided customization and lowered the cost of obtaining diversity and product variety. This allowed small-batch producers to compete with mass producers in fragmented markets, thus undercutting the cost advantage of scale economies in vertically integrated corporations. Just as outsourcing and a growing export orientation globally had intensified competition in low-priced markets, the diffusion of microelectronic technologies worldwide lowered the cost of flexible production and 
increased competition in quality-conscious markets as well (Appelbaum and Batt 1994, Piore and Sabel 1984, Feenstra 1998).

In this volatile environment, firms must now compete on the basis of quality, flexibility, product variety, quick turnaround times, timely deliveries and low cost. For example, the most competitive firms are not only cost-efficient, but also flexible. They have the capacity to produce a wide range of products and switch their production lines rapidly from one to the other, while holding down ever decreasing inventory levels. A Hong Kong sweater company with 200 workers for instance, can work on twenty different styles at the same time, some with orders as small as 150-300 pieces; another Chinese denim manufacturer went from producing 3-4 items to over 300 different items, and reduced its lead time from 45 days to 30 days; another Hong Kong company can produce 70 different kinds of yarns a month (Berger, Gartner and Karty 1997); an Indian silk furnishings manufacturer has a repertoire of 2000 designs that it can draw on at any time to produce batches as small as 50-150 meters, even while its profit margins reach nearly 40 percent (Tewari 2005).

These changes and the new demands they make on firms have scrambled the old logic of stable demand, large volumes, throughput and low unit costs in vertically integrated hierarchical firms - pushing corporations to search for innovative ways of coping with the growing uncertainty of demand and the requirements of the new competition. The alternatives that emerged in the 1980s and 1990s to old-style mass production came to be divided into two (stylized) categories - 'high road' approaches based on flexibility, understanding of different markets, innovation and new ways of sharing and defraying risk, versus 'low road' strategies based on low wages as the prime source of advantage.

The 'low road' was associated with competition on the basis of cost. Its focus on cutting costs put pressure on wages, contractual relationships, overheads, and scale (Piore 2002). This road generally fetched very low margins. Low margins pushed companies toward building up revenue with volumes. Labor saving automation, coupled with long 
runs of relatively simple goods provided some profits, but the approach involved no fundamental changes in the organization of work or in management practices (see Piore 2002, Piore and Sabel 1984, Humphrey and Schmitz 2000, 2002, Schmitz and Knorringa (2000), Tendler 2001, 2003). Low-road strategies often contributed to a 'race to the bottom,' especially in highly footloose industries such as textiles and apparel, where retailers and buyers sought to pass off more and more tasks down the chain to their suppliers and rising outsourcing shifted production to sites with lower and lower wages and factor costs around the globe.

The second strategy, of following the 'high road,' was to upgrade - move upmarket to higher value phases of the production process, to higher value goods, improved products, and processes. This approach involved competing on the basis of improved quality, product differentiation, the ability to produce a wide array of product variety and respond more rapidly and flexibly to changing market conditions and to the volatility that characterized demand (Piore 2002, Tendler 2001a, 2001b, Humphrey and Schmitz 2002). In many cases these work systems involved a fundamental restructuring of the work organization and the adoption of innovative work practices diffused from the Japanese system of just-in-time inventories, quality circles and continuous improvement. The actual organization of work and inter-firm relations in the high road approach have taken many different forms and are called by different names - lean manufacturing (Dertouzos, Lester and Solow 1988, Cole1980), flexible specialization (Piore and Sabel 1984, Brusco 1982), high performance work systems (Appelbaum and Batt 1994) and so on. In reality elements of the so called 'low road' were often mixed in with 'high' road practices. E.g., the same firm may have some low road operations (and plants) and some high road practices, or the same firm that operated as low road at one point in time may operate with higher performance work practices at another time. (We will return to these new organizational forms momentarily).

In the textile and apparel sector the earliest shifts were associated with a search for lower costs. This manifested in three ways throughout the 1970s, 1980s and 1990s: (1) Extensive outsourcing (of apparel assembly) first locally, and then to suppliers in 
lower wage sites across the world, and (2) the rising power of large retailers and corporate buyers based in industrial countries (such as Gap, Nike, Walmart) who played a key role in organizing and coordinating these emerging global networks and clothing supply chains. (3) In the 1990s the rise of information technologies and the deepening power of retailers demanding timely supplies of apparel led to the rise of "lean retailing," or production relations associated with rapid replenishment of fast-moving stocks.

In response to changed market conditions and the demands for flexibility described above, an extensive vertical disintegration or corporate restructuring followed. Throughout the 1980s and 1990s, firms externalized many relations, functions and operations that had been internal to the firm previously. Many large producers shut down parts of their in-house production and began to source increasing amounts of the total value of their products from subcontractors outside the firm-initially locally and then off-shore (Herrigel 2004). Firms sought to reduce inventories, shift from dedicated equipment to flexible productive arrangements and build strategic alliances with their suppliers and other firms to lower costs as well as to insure against the risk of supplying increasingly varied products to volatile markets. Subcontracting relations proliferated. Indeed, in the 1980s new kinds of branded apparel merchandisers arose (such as Liz Claiborne and Nike) who owned no factories. These branded "manufacturers without factories" such as Liz Claiborne, Nike, Reebok, controlled only marketing, branding and product design - the highest value functions in the production of apparel-and sourced their entire stock from suppliers across the globe (Gereffi 1994, 1999, Appelbaum and Gereffi1994).

A large literature emerged in the 1980s and 1990s to analyze this growing externalization of contracts and the rise of networked forms of production. Many scholars looked at these complex inter-firm relations through the lens of transactions costs, asset specificity, implicit contracts, and 'bundles' of property rights associated with the shifting boundaries of the de-verticalized firm (Williamson 1975, 1985, Alchian and Demsetz 1972, Hart 1989, Hart and Holmstrom 1987, Ben-Porath 1980, Kreps and Wilson 1984). Using notions of incomplete contracts and asymmetric information (in the 
face of uncertainty), they examined how problems of asset-specificity, "lock-ins," or expost monopoly power generate different kinds of inter-firm or buyer-supplier relations over time (Hart and Moore 1988, Pfeffer and Baron 1988). In the cases were the ties are the most hierarchical, small suppliers remain locked into generally exploitative relations with large buyers, while in other cases where efforts linked to the building of trust in the face of uncertainty helped build more relational and mutually dependent ties, buyers and suppliers gained flexibility through strategic specialization and repeated, long-term contracts (Johansson and Mattsson 1987, Granovetter 1985, Miles and Snow, Sabel 1989, Piore and Sabel 1984, Feenstra 1998. $)^{21}$

The literature on the textile and clothing industry identifies three broad kinds of subcontracting patterns in apparel ranging loosely along the continuum of 'low to 'high' road work practices. The most common kind of subcontracting centered around exportoriented apparel assembly, where firms, often in low-cost settings performed simple operations - such as cutting and sewing of inputs (raw material and accessories) provided by the buyer (such as JC Penny, Sears), and using designs and patterns provided by the buyer. The Mexican Maquiladoras ${ }^{22}$ were a classic example of this kind of subcontracting, as were, to varying degrees, the hundreds of small and medium producers in immigrant communities in cities like New York, Florida and Los Angeles to producers across developing countries. In these kinds of subcontracting ties suppliers add the lowest value in the supply chain and cost-reduction is a general and consistent pressure (Herrigel 2004, Gereffi 1999).

The second pattern of supply is the so called original equipment manufacturing (OEM) model where suppliers take on many more responsibilities than merely cutting and sewing pre-designed products using inputs provided by the buyer. OEM suppliers marshal a wider range of capabilities - providing design inputs, developing prototypes, working with the buyer to source inputs and accessories, package and finish the product, and in so doing learn about and obtain control over a wider range of upstream and

\footnotetext{
${ }^{21}$ See Pfeffer and Baron (1988) for an excellent review of the first generation of this literature

${ }^{22}$ Maquiladoras were a Mexican organizational form where firms located in Mexico processes or assembled good for US buyers using inputs, parts, and specifications provided by the buyer.
} 
downstream (backward and forward) linkages in the process of clothing production (Gereffi 1999, Gereffi et. al. 2004). Some have called OEM production "full-package" supply (Gereffi 1994, 1999, 2004), where supplier are not only able to capture a greater share of the total value added to the final goods they produce, but have longer-term, more relational ties with their buyers. Many East Asian firms in Taiwan, South Korea, Hong Kong and now China, fit these traits. In reality of course, the boundaries between these different forms of work organization - such as assembly operations and OEM supply are often blurred. A firm may be both at the same time: it may be a barebones cut-maketrim (CMT) operator for some buyers (such as Nike) but a full-package, OEM supplier for others (JC Penny, Dillards) (see Smith et. al. 2002, Pickles et. al. 2004).

A third form of work organization focuses on inter-firm relations that do not dichotomize between large versus small firms but focuses on the conditions under which firms of various sizes -- buyers and suppliers - are able to build collaborative ties and develop the capacity for ongoing adjustment to volatile and uncertain markets. Drawing on the striking success of Italian producers in the textile and garment districts of Prato and Emilia Romana, in coping remarkably flexibly with the fragmented markets and turbulent environment of the 1980s and 1990s, the 'flexible specialization' literature describes innovative and highly flexible production networks of horizontally linked firms that have jointly found ways to lower the cost and risk of dealing with uncertainty (Brusco 1982, Piore and Sabel 1984, Sabel 1989). This literature arose in response to the puzzle of growing productivity and innovation among small and medium firms in the Third Italy and parts of Germany in the absence of firm-level economies of scale and in the face of the same pressures that were creating dislocation in large companies. Loosely akin to Marshalian industrial districts with powerful external economies at the regional level, this form of industrial organization is associated with dense networks of spatially concentrated, sectorally specialized firms ${ }^{23}$ with strong, yet flexible, ties of trust and mutual dependence and supported by institutions at the local and regional level. Firms within these production networks use sophisticated technologies such as microelectronics

\footnotetext{
${ }^{23}$ Industrial districts are often associated with networks of small and medium firms, but firm size is not a defining characteristic of a flexibly specialized network - firms of any size with decentralized corporate structures can be, and are, a part of such networks.
} 
and information technologies that enhance the cost-competitiveness of small batch production, and allow firms to produce a wide variety of high quality goods that could be rapidly modified in response to changing market demands. These firms use a broadly skilled labor force and collaborative inter-firm relationships to achieve efficiency through inter-firm specialization and flexibility through a combination of competition and collaboration. The spatial and sectoral concentration of flexible production networks enables municipal and local governments to provide collective infrastructure (such as $\mathrm{R} \& \mathrm{D}$ and testing centers), public goods and services to the network as a whole at low cost, thus allowing even smaller firms to access quality services and technologies that they could not individually afford. The presence of active inter-firm institutions (such as producers associations), skilled workers and long term inter-firm collaborations allows the flexibly specialized production networks to achieve economies of scale and scope at the level of the network as a whole. Firms in flexible production networks, thus, compete on the basis of their ability to respond quickly to fluctuations in the market and to customer demand for variety and good quality, rather than by driving down labor costs. Instead of putting pressure on labor costs, the focus is on lowering indirect costs, lowering the costs of innovation through collaboration, reducing product development times, reducing lead times and overcoming the problems of rigidity and excess capacity that plague larger firms with dedicated equipment in turbulent environments (Piore and Sabel 1984, Appelbaum and Batt 1994).

The following table presents a stylized comparison of the various organizational forms discussed above - Market, Hierarchy, Relational Networks (Flexible Specialization) and Global Value Chain. 
Table 3: Comparison of Organizational Forms

\begin{tabular}{|c|c|c|c|c|}
\hline Key Features & Market & Hierarchy & Relational Network & Global Value Chain \\
\hline Normative Basis & $\begin{array}{l}\text { Contracts, } \\
\text { Property-rights } \\
\end{array}$ & $\begin{array}{l}\text { Employment } \\
\text { Relationship }\end{array}$ & $\begin{array}{l}\text { Inter-dependencies, } \\
\text { complementary } \\
\text { strengths }\end{array}$ & Contracts, Coordination \\
\hline Menas of Communication & Prices & Routines & Relational ties & $\begin{array}{l}\text { Thinly Relational', prices, } \\
\text { codified transactions }\end{array}$ \\
\hline $\begin{array}{l}\text { Volume of information } \\
\text { flowing across linkage }\end{array}$ & Low & $\begin{array}{l}\text { Varied - based on } \\
\text { tandard bureaucratic } \\
\text { demands }\end{array}$ & High & Medium \\
\hline $\begin{array}{l}\text { Degree of } \\
\text { Interdependence }\end{array}$ & Low & Internalized & High & Medium to low \\
\hline $\begin{array}{l}\text { Methods of Conflict } \\
\text { Resolution }\end{array}$ & $\begin{array}{l}\text { Haggling, Courts } \\
\text { for enforcement }\end{array}$ & $\begin{array}{l}\text { Administrative fiat, } \\
\text { Supervision }\end{array}$ & $\begin{array}{l}\text { Norms of reciprocity, } \\
\text { Reputational concerns }\end{array}$ & $\begin{array}{l}\text { Competitive switching, } \\
\text { Multiple partners }\end{array}$ \\
\hline Degree of flexibility & High & low & $\begin{array}{l}\text { High at the level of the } \\
\text { system, medium in } \\
\text { terms of mutual ties }\end{array}$ & High \\
\hline $\begin{array}{l}\text { Degree of adaptability } \\
\text { within the system }\end{array}$ & High & Low & High & high \\
\hline System-wide adaptability & High & Low & Medium to low & High \\
\hline $\begin{array}{l}\text { Amount of commitment } \\
\text { among parties }\end{array}$ & Low & Medium to high & High & Medium to low \\
\hline Tone or climate & $\begin{array}{l}\text { Precision and / } \\
\text { or suspicion }\end{array}$ & Formal, Bureaucratic & $\begin{array}{l}\text { Open-ended, Mutal } \\
\text { benefits }\end{array}$ & $\begin{array}{l}\text { Precision, competitive, } \\
\text { pragmatic }\end{array}$ \\
\hline $\begin{array}{l}\text { Actor preferences of } \\
\text { choices }\end{array}$ & Independent & Dependent & Inter-dependent & Limited interdependency \\
\hline Mixing of forms & $\begin{array}{l}\text { Repeat } \\
\text { transactions, } \\
\text { contracts as } \\
\text { hierarchical } \\
\text { documents } \\
\end{array}$ & $\begin{array}{l}\text { Informal } \\
\text { organization, Market- } \\
\text { like features, Profit } \\
\text { centers, Transfer } \\
\text { pricing }\end{array}$ & $\begin{array}{l}\text { Status hierarchies, } \\
\text { Multiple partners, formal } \\
\text { as well as informal rules }\end{array}$ & $\begin{array}{l}\text { Tight linkages and } \\
\text { pragmatic relationships }\end{array}$ \\
\hline Spatial effect & $\begin{array}{l}\text { Clustered and } \\
\text { dispersed }\end{array}$ & Dispersed & Clustered & $\begin{array}{l}\text { Clustered and dispersed, } \\
\text { linked nodes }\end{array}$ \\
\hline
\end{tabular}

Source: Adapted from Stugeon 2003, Pp. 484, and Powell 1990, Pp, 300 cf. Sturgeon. 
In the apparel sector outsourcing was closely tied to the off-shoring of work and to the internationalization of production. As Table 3 shows, imported intermediate inputs into the textile and apparel sectors of the US and several countries in Europe increased dramatically between the late 1970s and 1980s. Technical change and deep reductions in transportation costs reinforced this global dispersion of production, allowing firms to "slice their value chain" and take it to sites where they had access to the resources, knowhow and factors that they needed at the lowest possible costs - a process of centralized control over the chain, combined with global dispersal of production that many have called 'vertical specialization' (Krugman cf. Feenstra 1998).

Table 4: Out-sourcing and Off-shoring of Labor-Intensive Work - Late 1970s to 1980s

Ratio of Imported to Domestic Intermediate inputs - Textiles, Apparel and Footwear (Percent).

\begin{tabular}{lrrr}
\hline & $\begin{array}{l}\text { Early } \\
\text { Country }\end{array}$ & & \\
& Late 1970s & Mid-1980s \\
\hline Canada & 41 & 50 & 60 \\
France & 15 & 26 & 42 \\
Germany & na & 49 & 64 \\
Japan & 3 & 6 & 9 \\
UK & 19 & 33 & 48 \\
USA & 7 & 6 & 13 \\
\hline
\end{tabular}

Source: Audet, 1966 cf. Feenstra 1998 p. 39.

The first round of outsourcing began in the early 1970s when US and EU buyers increasingly began outsourcing apparel assembly to East Asian firms ${ }^{24}$ - in Taiwan, South Korea, Hong Kong and Singapore in the 1970s, and then to firms across Latin America, South Africa, other parts of Asia and especially to China in the 1980s and beyond. This outsourcing was driven by several factors, as we have noted - the high costs of operating vertically integrated systems in the face of volatile and unstable markets, and the 'retail wars' especially in the US in the 1980s between traditional supermarkets and newer retail formats such as direct purchase, mail-orders distributors,

\footnotetext{
${ }^{24}$ Japan was the earliest exporter of textiles and apparel to Western buyers in the 1950s and 1960s.
} 
hyper-markets, specialty stores and private labels at mass merchandise department stores that were all competing for the same consumer markets and sought to procure more and more varieties of apparel at lower and lower prices and in shorter and shorter turnaround times (see Gereffi 1999, Appelbaum 2005, and Lichtenstein 2005).

The rapid spread of apparel production to industrializing countries between the 1970s and 1990s was not only the result of market forces and changed market conditions; it was also actively shaped and reinforced by policies in developed and developing (buyer and supplier) countries. For example, the MFA helped shape the spread of apparel production and exports to quota countries across industrializing countries. Within developing countries these trends were accompanied by the rise of export processing zones, the investment by governments in industrial parks and special economic zones geared toward attracting export-oriented FDI, and procedures that made it easier for firms to export and repatriate profits. In industrial countries the trends were accompanied and aided -- by the crafting of special legislation that encouraged outward processing trade (OPT) or 'production-sharing' - such as the '807' rule in the US that waived the double taxation of US goods (textiles and apparel and consumer electronics) re-imported into the US after assembly operations in Mexican Maquiladoras, or by tax and tariff concessions awarded to contract manufacturers on Europe's Mediterranean rim, Turkey or post-socialist Eastern Europe who assemble apparel for European retailers and buyers under Europe's Outward Processing Trade rules (see Taplin 1994 and Gereffi 1999 for evidence from the US, and Smith et. al 2004 for evidence from Europe).

\section{Section 3: The Off-shoring of Production and the Global Value Chain Framework}

As global outsourcing has intensified, several frameworks have emerged to make sense of the growing integration of global production networks. The global value chain framework has emerged in recent years as an increasingly popular conceptual framework for studying the evolution of export-based industries and incorporating analyses of globalization into development studies (Bair 2005, Gereffi 1994). This literature, rooted in World Systems theory (Hopkins and Wallerstein 1986, 1994) and later extended by 
Gereffi and colleagues (Gereffi 1994, 1999, Gereffi and Korzeniewicz 1994, Appelbaum and Gereffi 1994, Bair and Gereffi 2002, Gereffi, and Kaplinsky 2001, Humphrey and Schmitz 2002, Gereffi, Humphrey and Sturgeon 2005) analyzes how specific industrial sectors and production systems change as they become globalized, and uses the 'global value chain' (or commodity chain) as the unit of analysis - as opposed to the firm, sector, or region. A global value chain is defined as a "network of labor and production processes whose end result is a finished commodity." ${ }^{25}$ In contrast to Porter's (1990) use of the value chain, the global value chain framework is not firm-driven. Its focus is on how various functions of a product's (or industry's) supply chain are splintered and globally dispersed. Given that the concept originated in a series of analyses carried out in the 1980s and 1990s of historical and contemporary trade, global capital flows, and the differential outcomes of Foreign Direct Investment (FDI) ${ }^{26}$ the GVC framework focuses specifically on the global linkages of the various bundles of economic activity or processes - from design to product development, to production, to branding, marketing and distribution -- that are part of an industry's supply chain, and which are involved in producing and bringing a final product to market.

The framework seeks to understand both the organizational dynamics of global economic activity - the vertical linkages between firms at different nodes of the chainas well as its development outcomes (Bair 2005). The organizational dynamics of the global supply chain, in this view, clarify not only the (uneven) developmental outcomes of global production processes, but provide a method to study the place of a country (and its industries) in the international economy and its prospects for mobility within it. Thus, in more recent work in this tradition, the concept of industrial upgrading figures prominently and many studies have focused on how a country's industrial development

\footnotetext{
${ }^{25}$ Hopkins and Wallerstein (1986, 1994), Gereffi and Korzeniewicz (1994).

${ }^{26}$ Some researchers asked why FDI had been associated with such different developmental outcomes in Latin America and in East Asia - why had FDI been growth producing in East Asia but exploitative and immiserising in Latin America. Gerrefi (1994) found that the answer lay in the fact that in Latin America multinationals had controlled producer-driven resource based industries with few local spillovers, while in East Asia, FDI had been associated with buyer-driven export oriented industries (apparel, toys). Coupled with the way in which East Asian governments protected their domestic markets (from entry by western retailers), and strategically promoted local industrial growth (Amsden 1989), the procurement oriented interests of industrial country retailers in East Asia had helped fueld exports and export-driven growth.
} 
trajectory or industrial upgrading prospects are shaped in different ways by participation in different kinds of value chains (Humphrey and Schmitz 2002. See Bair 2005 for a recent review).

The global value chain can be analyzed along four dimensions according to Gereffi (1994, 1995) - (1) Input-output structure, (2) territoriality (where the activities at each node of the chain are geographically carried out), (3) governance (or buyer-supplier relations) and (4) Institutional context. Governance of the chain refers to who coordinates the various economic activities within the chain, how value is generated at each node and how it is distributed. (Value is measured variously as profits, value added, or rates of return on investment). The nature of the chain and its governance structure thus become key variables in analyzing how power or control is exercised in global production networks and how upgrading may occur. Institutional context refers to national and international policies (trade policy, customs regimes) and the institutional frameworks that shape the processes of global production and exchange, and hence shape the character of the global value chains that emerge (See Smith et. al. 2002 on how the transformation of post-socialist production networks and the specific politics of EU accession have shaped quite distinct production chains relative to chains emerging out the US).

The framework distinguishes between two types of commodity chains-'producer driven' and 'buyer driven.' In producer driven commodity chains, large, integrated (often multinational) firms coordinate production networks and play a central role in controlling the industry's backward and forward linkages (Gereffi 1994, Thun 2000). Control of the chain is embedded in the lead firm's control over production, and there are significant barrier to entry into product design and development due to high fixed and sunk costs and the presence of proprietary technology. Capital and technology-intensive products such as automobiles and heavy machinery are classic examples of producerdriven chains. Buyer-driven commodity chains are characterized by decentralized production networks, usually dispersed globally, that are coordinated by lead firms at the retail end who control design, marketing, and branding. Control of the chain in this case 
is de-linked from production, and many of the most powerful branded retailers such as Nike and Liz Claiborne own no factories - they do not necessarily make in order to sell. Labor intensive sectors such apparel (and some agricultural products) are classic examples of buyer-driven chains where large retailers, marketers and branded merchandisers, such as J.C. Penny, Reebok, Sears, Nike, Liz Claiborne and Wal-Mart, play pivotal coordinating roles (Gereffi 1999, Bair 2005).

The global value chain framework's main contribution was to situate the central role that retailers (commercial capital) were playing in organizing the global production and distribution of apparel and textiles since the 1980s. The central premise of the framework was that market access into key industrial markets (quota markets till recently) such as the US and EU is controlled by powerful retailers and large branded merchandisers who, since the 1970s and 1980s have scoured the globe for low cost suppliers to establish elaborate, globally dispersed clothing supply chains which they coordinate and drive. As Figure 1 shows, retailers who coordinate far-flung global garment assembly and production networks capture the bulk of the value generated in clothing exports because they control the highest value activities in the clothing chain design, distribution, branding and market access. 
Figure 2: Comparison of the Flow of Value Added Across the Indian Clothing Value Chain: Evidence from Men's Cotton Shirts and trousers

Distribution of Value Added across the Indian Clothing Chain:

Men's cotton shirts/unit, Men's Khaki causal trousers/unit
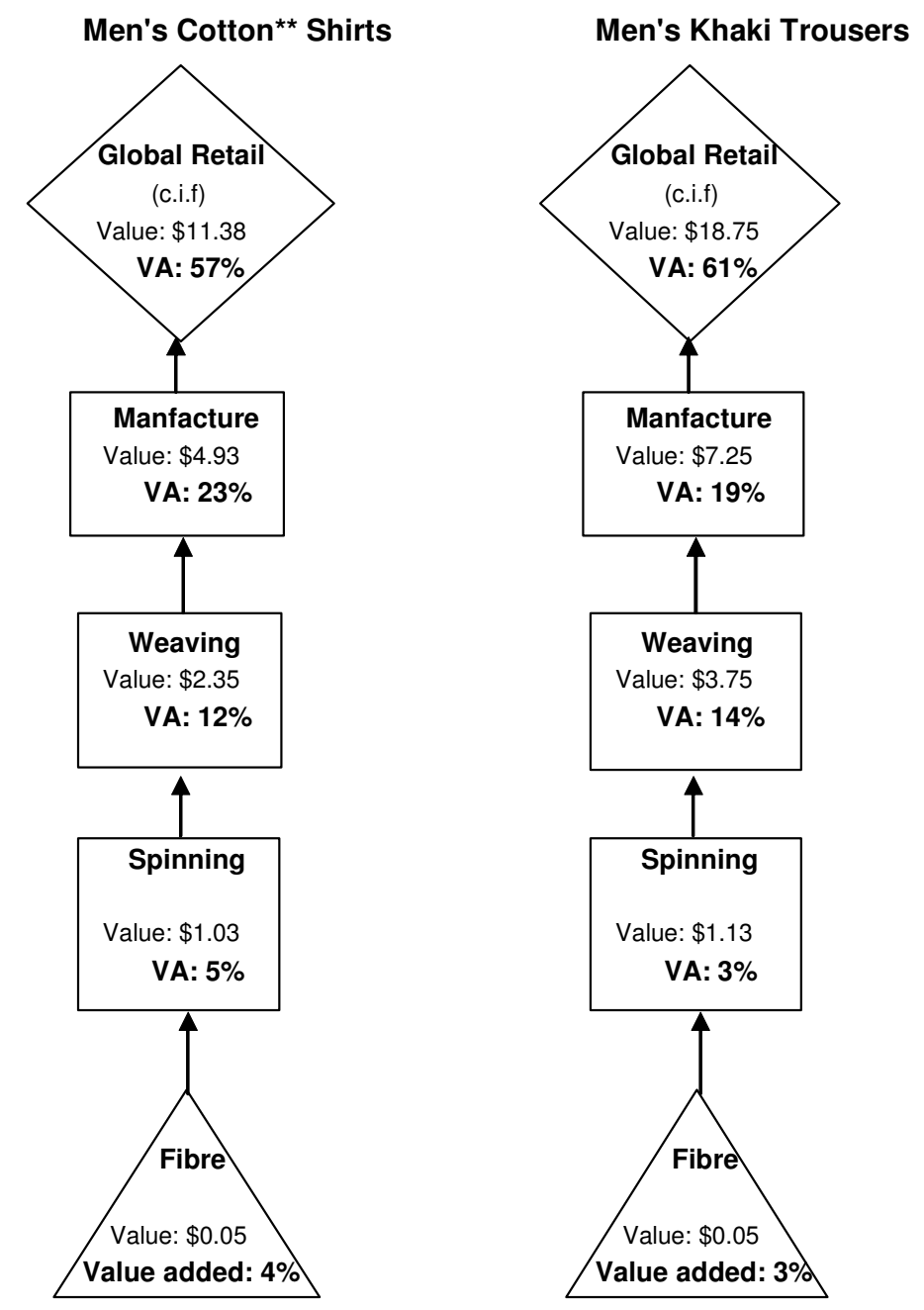

Source: Calculated from KSA Technopak's analysis of value added at each stage of processing in India of Men's cotton shirts and khaki trousers. * All costs, except retail, are based on input and manufacturing costs in India.

Reported in: Singhal et. al. 2004, "Creating Value in the Textile and Apparel Supply Chain," Textile Outlook International, January-February 2004 pp. 141.

**Poplin powerloom fabric

Figure 2 shows the distribution and costs (value) as well as value added at each key stage of the production of men's casual cotton shirts and Khaki trousers produced in India using Indian made fabric (based on survey data reported by KSA Technopak in Singhal 2004). The calculations are on a per-unit basis. The figures show that more than half - 57 percent -- of the value of men's casual cotton shirts (valued at $\$ 11.40$ ) is 
generated at the level of retail where design, branding and marketing are controlled by the global buyer. Actual store values may be even higher. Twelve percent of the shirt's value is added at the fabric stage and 23 percent in manufacturing. The numbers are starker still for men's trousers, where almost two-thirds of the value of men's casual Khaki pants (61 percent) is added at the level of retail (controlled by global buyers), only 19 percent is added at the level of production and 14 percent at the level of fabric production. India is a relatively late entrant into global apparel exports, and global buyers have only just begun to organize buying networks there; among older apparel exporters these numbers may be even more stark.

Globally, based on figures assembled by the United States International Trade Commission, it is striking to find that despite nearly three-quarters of all apparel exports originating from developing countries today, retailers and buyers in industrial countries still control a bulk of the value added (See Table 5 below). Though there are few barriers to entry in apparel production (other than demands for scale and quality under the new competition), entry barriers rise as one moves up the chain toward higher value functions such as design and marketing. The most lucrative portions of the value chain design, distribution, branding and marketing -- therefore remain in the hands of industrial country buyers despite the extensive global dispersal of production. 
Table 5: Distribution of Global Value Added in Textiles and Apparel

Distribution of the Global Share of Value-Added in Textiles and Apparel (Percentage)
Textiles
Industrialized countries (Total)*
Developing Countries (Total)**
Apparel
Industrialized Countries (Total)*
Developing Countries (Total)**
Source - Calculated from US ITC 2004, Table 1-4, pp. 1-18.
* EU, North America, Japan, Eastern Europe and the former USSR
** North Africa, Sub-Saharn Africa, Latin America, South and East Asia (excluding China), West Asia and Europe
A glaring omission in these data is China's share of value added; but even assuming that China adds 10\% to total value added,
i.e., nearly half as much as all other developing countries combined -- a bulk of the share of value added still remains with
global buyers and importers

The distribution of value added across the supply chain is central to the global value chain framework's attempt to turn the value chain heuristic into a mechanism for identifying the 'levers of upgrading' or potential development opportunities available to suppliers (and countries) who participate at different nodes in various clothing value chains. The proponents of the framework argue that in buyer-driven chains such as textiles and apparel for example, firms in low-wage, industrializing countries are typically found at the bottom end of the commodity chain, engaged in assembly or basic production under specification from large retailers or marketers (or their agents), who define the product and its design and control its marketing and distribution-essentially determining 'what is to be produced, when, how, .. how much and by whom (Humphrey and Schmitz 2002:1021). As newer countries enter into export markets, and as investment and export structures shift, the place of different countries in these commodity chains also changes, bringing with it the prospects for upgrading. The contention of the GVC framework is that these changes, together with the understanding that suppliers gain over time of what the barriers to entry are at each successive node of the chain, and the skills and competencies required to enter higher value nodes, may enable assemblers to leverage this knowledge with the help of governments and local institutions to move up 
to more complex roles within the chain-such as "full-package production," then to original equipment manufacturing (OEM) and eventually to original brand-name manufacturing (OBM), where greater value can be captured (Gereffi 1999, Thun 2001).

Figure 3: Upgrading Across the Value Chain

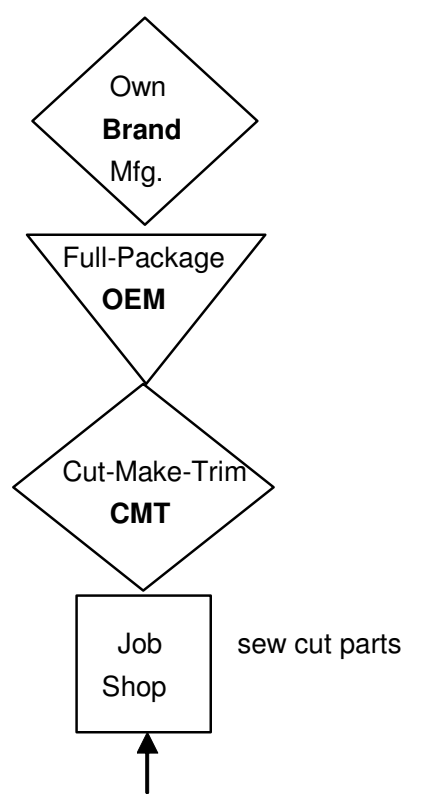

\section{Upgrading}

A major challenge for firms and policymakers in industrializing countries therefore, according to the GVC framework, is to understand how and under what conditions firms can move 'up the value chain' so that industrial upgrading may occur. The dangers are that low-end firms in low cost regions or countries may remain trapped at the lowest level of assembly-without acquiring the capabilities of moving into more complex production activities - and thus dependent on lead firms located in industrial countries. If low costs are the only factor driving the lead firm's sourcing decision from a particular set of firms, then such assemblers face the risk of being left behind when even-lower cost assemblers emerge in other countries (Thun 2000, Gereffi 1999, Dolan and Humphrey 2000). 
Figure 4: Buyer Categories and Demands on Suppliers

\begin{tabular}{|c|c|c|c|c|c|c|c|}
\hline Buyer Category & Examples & $\begin{array}{l}\text { Product } \\
\text { Quality }\end{array}$ & Price & Brand & Batch size & $\begin{array}{l}\text { Demands on } \\
\text { Supplier }\end{array}$ & $\begin{array}{l}\text { Relationsip } \\
\text { with Supplier }\end{array}$ \\
\hline $\begin{array}{l}\text { Importer/Wolesa } \\
\text { ler }\end{array}$ & Traders & Broad range & Broad range & $\begin{array}{l}\text { Private } \\
\text { labels }\end{array}$ & $\begin{array}{l}\text { Small to } \\
\text { Medium }\end{array}$ & $\begin{array}{l}\text { Price } \\
\text { competition } \\
\text { isoften fierce }\end{array}$ & $\begin{array}{l}\text { Broad range - } \\
\text { hands-off, } \\
\text { price driven to } \\
\text { longer term }\end{array}$ \\
\hline Discount Chain & $\begin{array}{l}\text { Wal-Mart, K- } \\
\text { Mart, Target }\end{array}$ & Standard & Low & $\begin{array}{l}\text { Generic or } \\
\text { Store brand }\end{array}$ & Massive & $\begin{array}{l}\text { Low margins, } \\
\text { continuous } \\
\text { pressure to cut } \\
\text { price, timely } \\
\text { delivery }\end{array}$ & $\begin{array}{l}\text { Primarily } \\
\text { assembly } \\
\text { operations in } \\
\text { captive supply } \\
\text { or price driven }\end{array}$ \\
\hline $\begin{array}{l}\text { Mass } \\
\text { Merchandisers } \\
\end{array}$ & $\begin{array}{l}\text { Sears, VF, J.C. } \\
\text { Penny, Lands } \\
\text { End }\end{array}$ & Good & Medium & $\begin{array}{l}\text { Private } \\
\text { labels }\end{array}$ & Large & $\begin{array}{l}\text { Quality, timely } \\
\text { delivery, price }\end{array}$ & Broad Range \\
\hline $\begin{array}{l}\text { Department } \\
\text { Stores }\end{array}$ & $\begin{array}{l}\text { Dillards, } \\
\text { Bloomingdales, } \\
\text { Marks and } \\
\text { Spencer, Macy's, } \\
\text { Nordstrom }\end{array}$ & $\begin{array}{l}\text { Considerable } \\
\text { range - from } \\
\text { good upwards }\end{array}$ & $\begin{array}{l}\text { Medium to } \\
\text { High }\end{array}$ & $\begin{array}{l}\text { Store labels, } \\
\text { National } \\
\text { brands, } \\
\text { Private } \\
\text { labels }\end{array}$ & $\begin{array}{l}\text { Medium to } \\
\text { Large }\end{array}$ & $\begin{array}{l}\text { Quality, } \\
\text { consistency, } \\
\text { variety, some } \\
\text { design, short } \\
\text { lead times, } \\
\text { timely delivery }\end{array}$ & $\begin{array}{l}\text { Contractual, } \\
\text { varied }\end{array}$ \\
\hline & $\begin{array}{l}\text { Benetton, OId } \\
\text { Navy, Gap, } \\
\text { Banana } \\
\text { Republic, Ann } \\
\text { Taylor, } \\
\text { Abercombie and }\end{array}$ & & & $\begin{array}{l}\text { National } \\
\text { and }\end{array}$ & Medin & $\begin{array}{l}\text { Quality, } \\
\text { consistency, } \\
\text { pattern and } \\
\text { prototype } \\
\text { making; }\end{array}$ & $\begin{array}{l}\text { Broad range; } \\
\text { increasingly }\end{array}$ \\
\hline $\begin{array}{l}\text { Branded } \\
\text { Merchandisers }\end{array}$ & $\begin{array}{l}\text { Fitch, Nike, } \\
\text { Levi's }\end{array}$ & High & High & $\begin{array}{l}\text { International } \\
\text { brands }\end{array}$ & $\begin{array}{l}\text { Medium to } \\
\text { Small }\end{array}$ & $\begin{array}{l}\text { Increasingly 'full- } \\
\text { package }\end{array}$ & $\begin{array}{l}\text { relational and } \\
\text { longer term }\end{array}$ \\
\hline $\begin{array}{l}\text { High end } \\
\text { Fashion-oriented } \\
\text { branded } \\
\text { companies }\end{array}$ & $\begin{array}{l}\text { Ralph Lauren, } \\
\text { Donna Karan, } \\
\text { Armani, Gucci }\end{array}$ & Exclusive & High & $\begin{array}{l}\text { Global } \\
\text { brands }\end{array}$ & Small & $\begin{array}{l}\text { Quality, co- } \\
\text { design, multiple } \\
\text { skills }\end{array}$ & Relational \\
\hline
\end{tabular}

Participation in different kinds of chains can provide suppliers with different kinds of learning and open up different pathways for upgrading. (see Table 4). Thus, though there is a downward shifting of the costs of development and variability in nearly all cases from lead firms to their suppliers, continual pressure for cost reduction is likely to be felt most strongly if the supplier is stuck at the 'lowest value more standardized nodes of the value chain' or if the buyer services the low-end discount or mass markets (Herrigel, 2004). For example, in supplying to discount chains like Walmart, whose primary focus is on low-price, low margins, large volumes and timely deliveries, firms may make profits from large volumes, but learning - in terms of producing new, higher value products - can be limited. Branded merchandisers, such as Gap or Banana Republic by contrast look for suppliers with more complex capabilities than just volume, price and timeliness. They expect a fuller range of services from their suppliers - an 
ability to deal with shorter runs of variable designs, short pre-production lead times (e.g., in design and prototype development), participation in sourcing, design, logistics, and possibly warehousing ${ }^{27}$-- and hence look beyond considerations of price to suppliers who have the requisite skills, resources, technology, capital equipments and productivity to work closely with lead firms (Herrigel 2004). Where do these capabilities come from? How can firms move up (the so-called value chain) from simple assembly to acquiring more complex capabilities?

Global value chain researchers have documented the possibilities of at least four types of upgrading within value chains: (1) process upgrading - where suppliers carry out existing tasks in new ways so as to improve productivity, performance and profitability. This may occur through the adoption of better technology, or the adoption of higher performance work systems and more effective organizational practices (such as just-in-time inventory, teams, continuous improvement, six sigma, various quality certifications such as ISO 9000, 14000, and more sophisticated reporting systems). (2) Product upgrading: improved work performance may lead firms to move into higher value product varieties that fetch them higher unit values (quality upgrading). An example would be shifting from producing standard low-cost apparel to higher value shirts and jackets (3) Functional upgrading, or acquiring new, higher value functions that call for higher skills of operation - such as integrating design and product development with manufacturing, or integrating backwards into spinning and weaving from garment assembly, or forward into logistics, warehousing, distribution and branding. In the garment industry this could mean moving from a cut and sew operation to full-package supply where a manufacturer independently sources fabric, accessories and combining design inputs with original equipment manufacturing. Eventually, this can lead to the development of own brands, and thus 'own-brand manufacturing,' thus moving vertically up the chain (Humphrey and Schmitz 2002, Gereffi, Humphrey and Sturgeon 2005). (4) Inter-sectoral or inter-chain upgrading: where firms use economies of scope or skills learned previously while carrying out one activity to move horizontally

\footnotetext{
${ }^{27}$ However, these varied demands on suppliers do not automatically map into good working practices. As some researchers have shown, higher end buyers (such as Liz Claiborne) may have just as exploitative work relations at the level of their suppliers, as price-conscious discount chains (Collins 2003?).
} 
to a new sector. E.g, textile companies moving into sophisticated new fabrics used in non-apparel industries, such as automotive, aerospace and so forth. As Gereffi points out, lateral diversification of this sort was central to Taiwan's shift into more skillintensive sectors.

But how will all this come about? And what are the barriers to upgrading? The value chain literature provides only stylized typologies. It provides few insights into mechanisms or understandings of wider institutional processes by which upgrading actually occurs, why it occurs in some cases, in and some places, and not it others.

According to value chain researchers firms can upgrade depending on a number of factors - some specific to the nature of chain (or industry), some to their historical context, and some to their own capabilities. According to the GVC framework, four features shape the entry barriers or the ease or difficulty of entering higher value nodes in a chain: (1) the complexity of transactions, (2) degree to which information (about the skills and processes needed to operate at a node) can be codified (spelled out and made explicit instead of remaining tacit), (3) the specific demands that the technology or organization of production places on suppliers in particular industries (such as sophistication of technology and the costs of accessing it, the degree to which certain market conditions, such as time to market, variability of design are critical to competitiveness), and (4) the capability of the supplier.

However, there may also be tensions between firms that occupy different nodes of a chain and between buyers and suppliers themselves that may inhibit upward mobility. For example, in a study of Brazil's largest shoe cluster in the Sinos Valley, Schmitz found that the divergent interests of Brazilian firms situated at different ends of the value chain, and their very different ties with their American buyers made upgrading and adjustment difficult. The Sinos Valley shoe cluster in South Brazil, dominated by small and medium firms till the 1970s, went through two kinds of divergent shifts with the arrival of US buyers in the late 1970s. The American buyers sought to build a dedicated supply network, picking a few firms to tutelage, train, and grow, and placing large orders 
with them to encourage them to develop their own local supply chains. In this first round of relationships, the US buyers were a key source of upgrading for the firms that were part of their value chain. The buyers "studied the market, developed models and product specifications, helped producers in the choice of technology or organization of production, inspected quality on site, and organized transport, logistics and payments." (Humphrey and Schmitz 2002: 1023). A clear division of labor evolved in the cluster the Brazilian suppliers focused on production while the US buyers controlled product design, logistics and marketing.

While initially this arrangement led to rapid growth and learning for the cluster as a whole, its limits soon became evident. By the early 1990s, when cheap Chinese shoes began to flood the US market, Brazilian exporters came under severe price pressures, including from their own buyer. In trying to get out of direct competition with the Chinese the local footwear association in Sinos Valley developed a collective initiative to move up-market and raise the image of Brazil's shoes worldwide and in the US. However, the upgrading never got off the ground - it was blocked by a subset of the cluster's firms who directly exported to the US buyers as part of their direct supply chain. These exporters feared to encroach upon an activity - design and product development that the buyer regarded as its turf and core competence. The asymmetric and dependent relationship with a monopsonistic buyer thus derailed the cluster's diversification (See Schmitz 1999 and Humphrey and Schmitz 2002, Schmitz and Knorringa 1999). Moreover, those occupying higher ends of the value chain sought to monopolize the activities at the preferred nodes by institutionally diminishing the degree of competition at the node of choice.

In the Indian apparel industry as well, similar trends are apparent in the way in which some cut-make-trim contractors describe their relationship with their buyers. One large CMT contract manufacturer based in Bangalore reported how they had experienced significant price deflation after the MFA was phased out in January $2005{ }^{28}$ To deal with the continual pressure on prices the CMT exporter said they had never considered getting

\footnotetext{
${ }^{28}$ In contrast to what full-package exporters in the same city had reported - of having been able to hold the line on prices so far, post-MFA.
} 
involved in design and pattern making for their buyers (several of whom were brandname US merchandisers) because "that is their core advantage. Why should they continue to work with us if we compete with them on their own ground?" (Interview, April 2005). Instead the firm had invested in state of the art production planning and tracking systems to reduce wastage, improve consistency, increase productivity and shore up margins. However, realizing the limits of the cost-cutting route, the firm was indeed planning to upgrade into design but in a different way - it was exploring partnerships with third-party designers and US department stores that needed to fill their racks with as much variety as possible.

It is however also important to not conflate the adoption by suppliers of higher value activities as necessarily voluntary - sometimes it may simply be the outcome of firms higher up the chain passing additional functions and tasks (logistics, warehousing) down to the supplier to defray its own risk and pare down costs (see Bair 2005, Smith et. al. 2004, Fitter and Kaplisnky 2001, Gibbon 2001, Dolan and Tewari 2001, Abernathy et. al 1999). Is that really upgrading then? Such firms, burdened by extra costs may well seek to pass them on to their own workers at the bottom of the chain - squeezing them without the basic job security, skills and working conditions associated with reaping the rewards of adding value. In an environment where buyers increasingly demand good quality, consistency, timely delivery and low cost, this would be short-sighted indeed.

In some cases upgrading has occurred as a result of tutelage, knowledge transfer and feedback between global buyers at the head of particular value chains, and suppliers lower down the chain. For example, in the case of Mexico's apparel industry, particularly jeans, as described in Bair and Gereffi 2001, 2002 and Rosenberg 2005, ongoing feedback from US retailers (and manufacturers who had established joint ventures in Mexico) led over time to the transformation of some Mexican suppliers from basic assembly in Maquiladoras to full-package supply as they absorbed more and more of the relatively higher value functions previously performed by their buyers - including pattern making, computerized cutting, fabric sourcing, packaging and distribution. As shown in Table 5, over time many of Mexico's Maquilas that began with export oriented 
assembly (such as Torreon's blue jeans suppliers depicted below) have grown to perform many additional functions (the shown by the shaded parts in the table below.)

Figure 5: Rising to Full-Package in Mexico's Blue Jeans Industry: Torreon in 1993-2000

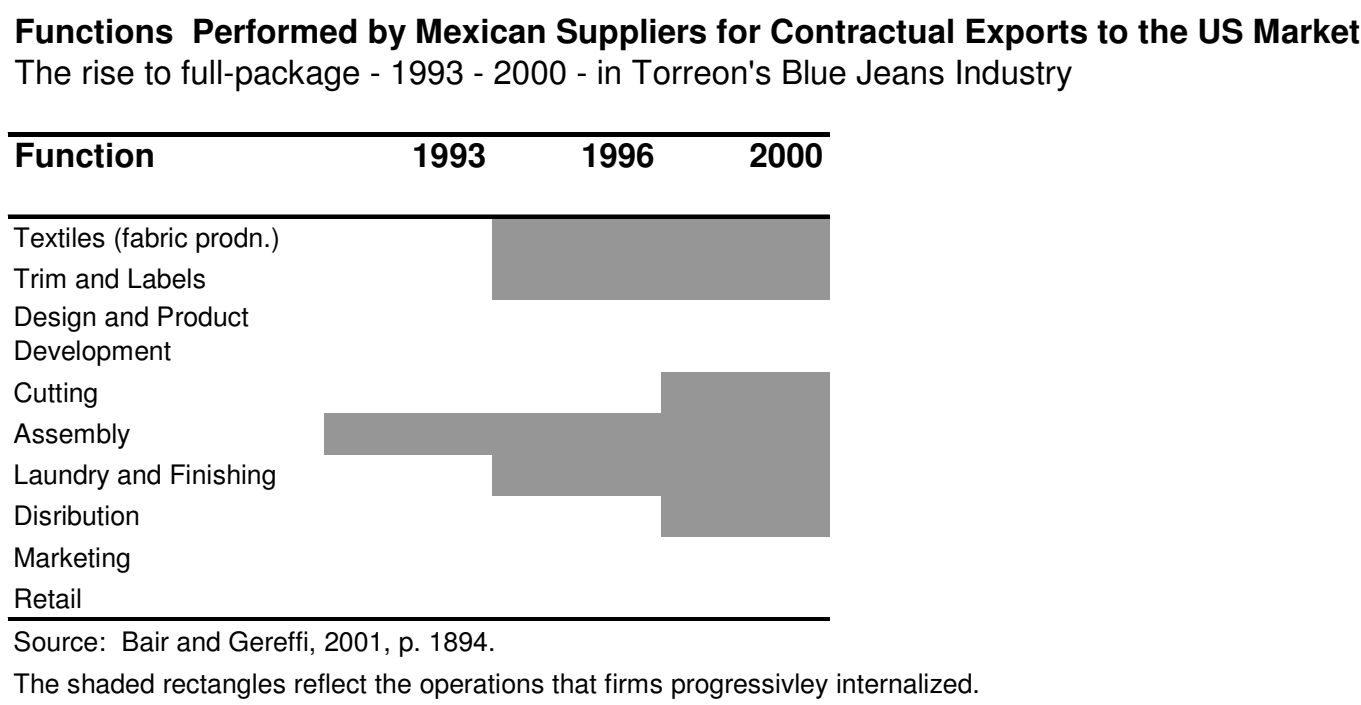

However, this 'vertical learning' has remained narrowly confined to a small subset of large Mexican exporters and joint ventures. For example, in Torreon's jeans cluster, depicted in the chart above, the top ten firms were large - with individual production capacities ranging from 135,000 to nearly half a million pairs of jeans per week, and average employment of 3000 workers per factory. Three of the ten were US subsidiaries, and one a joint venture, the remaining six were large Mexican firms. Even among this elite group, only four firms were 'full-package' suppliers - i.e., they received an order from their buyer and delivered the final product, not intermediates; an additional four were "half-package" suppliers in that they carried out all of the production activities (cutting, sewing, laundering and finishing) but did nor procure the fabric or accessories (Bair and Gereffi 2001:1895-6). Moreover, as other scholars have pointed out, these skills did not diffuse widely through the system to other firms (Piore et. al. 1996, 2002). The onus is therefore largely on domestic institutions - industry associations, public agencies and local universities -- to put in place wider institutional processes that will enable firms to learn - outside of value chains - and transform their 
work practices and capabilities to meet the demands of competing in a volatile markets in the face of intense competition. ${ }^{29}$

Indeed, one study found that Mexico's upgrading to 'full-package' was shaped in important ways by trade policies and the regulatory environment generated by its freetrade agreement with the US and Canada. In a study of NAFTA's effects on Mexico's apparel industry, Gereffi and Bair (1998 cf. Bair 2005) show how the massive increase in Mexican apparel exports to the US just after NAFTA reflected in part the response of leading US textile firms and clothing buyers to make use of the rules of origin in the new trade regime that favored US textile companies 'forwarding yarn' and fabric to Mexico for cutting, sewing and assembly. Encouraging the rise of Mexican "full-package" suppliers was thus also an effort to overcome Asia's lower cost textile exports to Latin America, reduce US buyers' dependence on Asian manufacturers and create a proximate base for rapid replenishment. In the process, Mexican firms became inadvertently locked into specializing in a narrower range of items for which either the rules of origin were favorable to fabric sourcing from the US, or for which replenishment demand was especially high. In the last few years firms in some key garment clusters in Mexico, such as Torreon, have turned themselves around by ceasing to compete with China for 'long cycle stock production items by becoming a flexible producer of quick, short-cycle, higher quality rapid replenishment orders (Rosenberg 2005). In other cases innovative government-university programs run in partnership with business associations have helped upgrade the skills and design capabilities of local producers to sell both at home as well as in niche, export markets - not via global buyers, but beyond them (Lowe 2003).

${ }^{29}$ In recent years multilateral agencies like the ILO, UNIDO, and various national and local governments have used the global value chain framework to map out the place of their domestic industries within global value chains to see how they can improve their position and generate and retain greater value both in domestic and export markets. Similarly, with the growing importance of "credence goods" and corporate social responsibility, NGOs and anti-sweatshop activists have also used with some success the global value chain framework to map out buyer-supplier linkages in the complex and fragmented global chains to identify the points of leverage at which to bring pressure to bear on major global buyers such as Gap and Nike to promote better codes of conduct and working conditions for workers employed in their suppliers' factories (Quan 2005, Bair 2005, Dolan 2004, O’Rourke 2002). 
A second kind of learning - or movement up the value chain - is evident in the case of East Asian exporters, notably Taiwanese and South Korean firms who were the earliest to enter into buyer-driven exports of labor intensive goods for the US market. Their ability, over long years of production, to master the process of fulfilling large orders to the exact specification of their buyers and perfecting their ability to meet exacting delivery schedules - aided crucially by public sector investments in ports, infrastructure and support institutions in their countries -- led to their rise as key middlemen or organizers (and coordinators) of full-package supply for industrial country buyers. Supplying to low end buyers such as K-mart in the 1970s, Taiwanese and South Korean (and Hong Kong) firms moved to supplying department stores, then major brand-name merchandisers such as Liz Claiborne, the Gap, Donna Karan and finally acquired the knowledge and ability to not only contribute centrally to the design, development and production strategy of their customers (Ralph Lauren to Gap, to Nike to Armani), and hence gained power within the value chain. One reason why East Asian suppliers were able to 'rise up the value' chain, when so many suppliers today get stuck at low-end segments of chain (e.g., the market-atrophying effects of suppliers ceding control over design to their global buyers as in the Brazilian case discussed above) could be the timing of the rise of East Asian exporters - in the late 1970s and early 1980s where there was less fierce global competition over apparel assembly and supply. A more salient reason is offered by Tendler (2001), and that is that in the East Asian cases the domestic market was always an important market-creating complement to the export market. ${ }^{30}$

But most importantly, using the tacit knowledge as well as the specific experience they gained about production management, many Taiwanese, South Korean and Hong Kong based apparel exporters, by the late 1980s and 1990s came to act as intermediaries for global buyers, distributing their orders widely across lower cost producers in Asia,

\footnotetext{
${ }^{30}$ It appears that similar changes may be occurring in China and India today. A recent account reported, for example, how after the re-imposition of quotas on Chinese garment exports by the US and EU in JuneJuly 2005, some large producers are turning to the domestic market for sales. With a growing middle-class with substantial purchasing power, this producer not only found that local consumers had money to spend on expensive clothing, but that there was a vast untapped domestic demand for good quality apparel. This firm thus not only comfortably sold all the items turned back by US and EU port authorities, but is adding a thousand more workers to increase capacity to cater to the domestic market (New York Times, October 20, 2005).
} 
Africa, and other countries (wherever quotas were available) and managing the process of input supply, production coordination and final dispatch of finished goods. These firms learned foreign languages, made regular visits to sites of triangle production (South Africa, Latin America, East Asia), used modern technologies (quick response electronic data interchange systems to communicate with their clients and focused their efforts on achieving consistency, quality and timely supply from their dispersed subcontractors (See Gereffi 1999, Berger Gartner and Karty 1997).

Spurred by retail competition in industrial markets and the growing movement among US retailers to 'buy direct' in the 1980s (Gereffi and Pan 1994), these intermediaries became "one-stop-shops" for US and European buyers. Referred to as "triangle manufacturing" (Gereffi 1994) this process of the emergence of large, capable and quite powerful contractors within global value chains defines an important shift in the exercise of power within these clothing chains. In a world of volatile demand and shortened product cycles, this mutual dependence of the buyer and the supplier gave tremendous clout to this new tier of actors.

The Hong Kong based garment trading company, Li \& Fung is a classic example of this kind of intermediary. ${ }^{31}$ Originally an exporter of silk and porcelain from China, $\mathrm{Li}$ \& Fung began to export garments and other manufactured goods to the US and Europe in the post-war period. With the rise of textile quotas under MFA, the company began to buy and sell quotas in the 1970s and 1980s and soon became an expert buyer and broker of quotas under MFA. In the course of its quota trades it established extensive links with thousands of Asian garment suppliers as well as with other suppliers and retailers across the supply chain. During the 1980s when more and more US and European retailers sought to by-pass importers and source directly from manufacturers, Li \& Fung became a broker and coordinator of regional production chains in Asia on behalf of foreign buyers. By 2001 it had 7,500 suppliers in 40 countries around the world, including India. In recent years Li \& Fung has moved into "product development, raw-material sourcing,

\footnotetext{
${ }^{31}$ This account is drawn from Abernathy Volpe and Weil 2004. For other discussions see Loveman nad O’Connell 1996.
} 
production planning, manufacturing control, quality assurance, export documentation and shipping consolidation" (Abernathy et. al. 2004). Most recently it entered into a licensing agreement with Levi's to design, manufacture and market men's tops under various Levi's labels and branded jeans in the US market.

The most significant shifts that make global intermediaries such as these tremendously powerful is the rise of 'Lean Retailing' and the growing importance of timeliness in the sourcing and supply of apparel. It is to this issue that we turn to next.

\section{Section 4: Lean Retailing, and Specialization: The return of proximity as a driver of apparel sourcing and supply.}

Dramatic shifts in information technology have transformed the structure of retail in recent years, and with it, the textile, apparel and retail relationship. These new technologies, such as quick response electronic data interchange systems that transmit point of sale information to the supplier in real time, have provided retailers and producers new and innovative ways of dealing with the volatility and uncertainty of global markets.

For example, take the case of a discount retailer such as Walmart or a department store such as Dillards. Walmart operates 5000 stores worldwide, and with annual sales nearing $\$ 300$ billion, Walmart's revenues are larger than Switzerland's (Lichtenstein 2005). Even with scales such as these, Walmart owns no factories. It sources its entire product from the thousands of suppliers it contracts with around the world, 3000 of them in China contributing nearly $\$ 23$ billion in sales. In moving volumes such as these to its global consumers, Walmart carries virtually no inventory. Using sophisticated technology and state of the art logistic management systems, Walmart "tracks consumer behavior with meticulous care and then transmits consumer preferences down the supply chain. Replenishment is set into motion immediately, with suppliers required to make more frequent deliveries of smaller and smaller lots" (Lichtenstein 2005: 13). To make this giant just-in-time inventory system work Walmart has mastered "lean retailing." For example, in its dealings with Proctor and Gamble $(\mathrm{P} \& \mathrm{G})$ and its suppliers, Walmart used 
its tracking technologies to gather highly detailed information about consumer tastes and used it to source its home care products from $P \& G$ 's supply chain much more accurately and profitably. By insisting that suppliers implement information technologies for exchanging sales data, adopt standards for product labeling and use modern material handling processes, Walmart conveyed continuous data on sales, inventories, and prices to $P \& G$ via satellite, enabling it to replenish its goods rapidly, accurately and most often, directly from the suppliers' factories to individual stores (Abernathy et. al 1999, Lichtenstein 2005).

Lean Retailing (see Abernathy et.al. 1999) refers to a set of business practices that allow buyers to manage risk in a volatile and uncertain business environment by sourcing in short, frequent cycles. This process of rapid replenishment allows retailers like Walmart, Dillards and scores of others, to respond quickly to variable demand without holding large inventories. Short lead times (or quick turnaround times) are critical for rapid replenishment. Buyers may replenish their stocks fortnightly, weekly, or even more frequently. These changes allow retailers to lower the costs of carrying variable designs while avoiding the trap of over-capacity and large inventories.

Lean retailing is supported by sophisticated information technologies, and logistics systems. Information technologies such as Electronic Data Interchanges (EDI) and bar-codes that allow point-of-sale information to be instantly transmitted to the suppliers' shopfloor - informing suppliers how much of a particular time-sensitive item has been sold on a daily basis. Increasingly, production tracking systems based on computer chips embedded in individual items that allow retailers to gauge the progress of an order - or its dispatch - in real-time are critical for Lean retailing to work. Equally critical are new forms of warehousing and sophisticated logistics and distribution systems that can quickly move goods from suppliers to the retailers' shelves (Abernathy 1999).

The importance of 'timeliness' in Lean Retailing has thus made proximate locations important in the sourcing decisions of buyers for fast-moving or quick-selling items, over and above considerations of cost. For example, although labor costs in 
Mexico are more than three times China's, US retailers source their replenishable items, such as jeans and T-Shirts, much more heavily from Mexico than from China. In 2003, US buyers sourced over $\$ 4$ billion worth of replenishable products from Mexico and the Caribbean Basin (amounting to $22 \%$ of all apparel sourced from these countries) compared to $\$ 1.3$ billion from China and other Asian countries (Abernathy et. al. 2004). Thus, the argument that the Lean Retailing literature makes is that despite lower factor costs in countries like China and India, proximate locations closer to the US - e.g, Mexico, the Caribbean basin, and Central America - will continue to be important sites for the sourcing of items that are replenishable. ${ }^{32}$ Using data from US retailers, and their Mexican and Asian sourcing patters, one study found that for products with replenishment needs of 10 percent, imports from nearby countries grew $37 \%$ faster (than from other locations.) With replenishment needs of $25 \%$ or higher, imports from nearby countries (Mexico) grew 45 percent faster than imports from more showed that products where rapid-replenishment was important grew much more rapidly from nearby sources (Mexico, Caribbean basin) than they did for Asia - China and South Asia (Evans and Harrigan 2005).

Traditional analyses hold that 'manufacturing performance is determined by the labor time required to produce an item,' but scholars studying modern production systems such as lean retailing argue that 'direct labor content is not the primary issue' (Abernathy et. al 1999). They find that companies that have adopted the new management practices, the new information technologies and the new organizational practices are the strongest performers, rather than those who merely improve their cost competitiveness. Comparing those who hold the lowest inventories (work in process and finished) and have the most flexibility to respond to changing market conditions, with those who focus primarily on cutting costs, these scholars find that they find that under current conditions of volatility and demand for timely delivery and rapid replenishment, "the sourcing option that offers the lowest direct cost is not always the most profitable" (Abernathy et. al. 1999: 126).

\footnotetext{
${ }^{32}$ Specifically, "goods that are ordered more than once per season are called replenishable, while goods that are ordered only once per season are 'non-replenishable' (Evans and Harrigan 2005:294).
} 


\section{Section 5: A Word About China}

In closing, I want to revisit the question of China and its remarkable performance in textile and apparel exports in recent months (after the removal of quotas, notwithstanding the recent re-imposition of restraints on it by the US and EU), and over the past two decades - ever since it came from behind to dominate global textile and apparel trade in 1998. I will make three points in this section.

Much has been written about China's low costs of production and its large scales of operation. Indeed, China's already large factories are becoming even larger, and together with Hong Kong based firms, are emerging as something of a model of the kinds of industrial organization - 'mega suppliers' with operations in sites around the globe that can take on the power of giant retailers and corporations such as Walmart (Richard Appelbaum 2005). For example, a factory complex in Dongguan employs more than 40,000 workers; its new Vietnam based operations will hire 65,000 workers-perhaps the largest under a single roof in the world; other globalizing Chinese companies have workers in the range of 150,000-170,000 worldwide (Lichtenstein 2005). As we noted earlier in the paper, China's superior export (and economic) performance, its large scapes of operations and its low costs of production have led many countries, firms and policy makers to focus on scaling up and reducing costs as a way to compete with and emulate China. Thus, the first point I want to make is that while clearly, size is important, especially in the case of China, the benefits of low cost and large scale production are easier to posit than to realize in an environment where demand is unpredictable and highly volatile. As we saw above, even the largest of firms are adopting a whole array of production practices and technologies that overcome the 'costs' of scale - i.e., rigidity, high inventories and narrow specialization. Without the ability to respond flexibly in a fast changing competitive environment, scale can be a burden.

The second point, therefore, is that China's low cost (CMT) model (of large runs and big volumes) is embedded within a range of other capabilities that allow production 
benefits to be realized more widely. In the Chinese case several factors have come together to alleviate the 'costs of scale,' so that even though, on the face of it China follows the classic CMT production model in apparel and textiles that has trapped many smaller supplier countries in dependent relationships with their global buyers, the outcome in China is relatively different. (It is important to be clear here that labor conditions remain hugely regressive in scores of Chinese factories (piece rates, long hours of work, no over time), but they are not monolithically bad across all factories nor the main reasons for Chinese superior productivity.) China's advantage rests not only on its low cost production operations, but how these operations are combined with two of the most important assets that allow its large scale operations to elude rigidities: the presence downstream (forward linkages) of the hundreds of highly experienced, and by now powerful, global intermediaries from Hong Kong, Taiwan and South Korea who manage the "Traingle Manufacturing" networks of apparel production, and who have honed their skills at producing - and getting other suppliers to produce -- output of good and consistent quality in a timely and adaptable way and at reasonable costs. As we saw, these firms have focused laser-like over the last decades to refine their ability to turn out goods of reliably good quality on time - meeting strict delivery schedules over and over again. It is this 'value,' of timeliness, consistency and quality, over and above low prices and volumes, that induces buyers in the US and Europe to negotiate large and repeated contracts with East Asian and Chinese producers. By 1995, Hong Kong SAR entrepreneurs operated over 20,000 factories and employed an estimated 41/2 to 5 million workers in China's Pearl River Delta alone (De Coster 1996 cf. Gereffi 1999, Berger, Gartner and Karty 1997). Since then, this number has only increased. This insertion of Chinese producers into sophisticated and highly internationalized marketing, management, design and distribution networks completely changes the valence between an ordinary CMT operation based on low margins and long runs, and the kinds of networks that are taking shape in China.

The other piece that changes the China story from being one of low costs and large scale alone to something much more is its embeddedness upstream (backward linkages) into a robust and diversified textile, accessories and inputs industry. China is 
among the largest producers of a wide range of fabric, and together with Hong Kong SAR's entrepreneurs has proximate access to some of the largest apparel accessory markets in East Asia. China's capability is therefore not only to assemble low cost apparel, but in its ability to link it directly with its large textile industry and input base. Today, when the dominant view, post-MFA is that rapidly consolidating retailers are increasingly reluctant to "move fabric around the world" (Tesco Interview, 2005), this linkage with a powerful textile industry is a major advantage. The government has played a central role in bringing inputs - of all kinds - spatially together in sites where production takes place. Seeing this rich input and institutional base, as well as productive capacity, the Textile, Chemical and Dyes association of the US decided in 2000-1 to open some of its largest and most sophisticated wet-processing operations in China (Interview, North Carolina, 2002).

Under these conditions, the scale of China's production capacities, their continually evolving quality, and the continuity of big orders (despite the recent safeguard measures) also gives Chinese firms the financial ability to access capital and new technology to upgrade their production process continuously e.g., China has been able to upgrade its production technology rapidly in recent years and the latest machines imported from Germany, Italy, Japan and the US is in use in many of its plants (Appelbaum 2005). Similarly, the massive scale of production and repeat orders from giant retailers gives Chinese firms the power to put pressure on fabric producers to constantly innovate to keep prices low. Thus, as many have argued, the Chinese are masters of the CMT model (Gibbon 2005), but their assets are not only their large production capacity and the related economies of scale and scope, but their close embedding within the higher value added functions of full-package supply of the Taiwanese, Hong Kong and South Korean turn-key suppliers who have decades of experience working with US buyers, and an excellent understanding of the demands of the American (and European) consumer market. The point is that, scale, without the Chinese mastery over lean production, consistent and timely delivery, and their reciprocal access to key global buyers and intermediaries would only add to overheads. 
My final point is that these advantages of production and market access that China enjoys today have been actively shaped by government policy over time. In the next few paragraphs I describe brief innovations of policy in the re-making of China's textile industry to illustrate my point. (This material is drawn primarily from Chandra 1998). When the Chinese government began to promote the textile industry as a key growth sector in 1978, it made two decisions. The first was to thoroughly modernize the textiles sector technologically; and the second was to link this infusion of new technology (and other initiatives) to a particular, strategic goal—of building market share. This goal of building up market share shaped the nature of the government's modernization program.

Chinese firms have invested over \$1billion annually in the import of new cotton and silk processing equipment since 1985. The state run Beijing Cotton Mill alone has invested close to $\$ 1$ billion in new equipment over the past ten years. These investments have gone into new machinery (such as rotor machines, and shuttle-less looms in spinning mills), as well as into new and innovative production systems such as statistical process control capabilities and machines that detect in-process defects. Between 1987 and 1996, for example, China invested in 68,000 modern shuttle-less looms while Indian firms invested only 8000 such looms in the same period (Chandra 1998). ${ }^{33}$ Similarly, with the use of better equipment, and key organizational changes, China's defect rates are half those of Indian textile firms (3-5\% in India, compared to 1-3\% in China, and 0.01$1 \%$ in advanced industrial countries like Canada.) [Even today, post-MFA Chinese firms increased investment in textiles and apparel by $\$ 13$ billion compared to just under $\$ 2$ billion in India (Business Standard 2005).]

But the government did not see the technological upgrading of the textile industry as a goal in-itself, rather it was a means for increasing China's market share at both, the low-cost, high volume and the high value-added, low-volume ends of the global market. Exports were key to this two-pronged strategy, as was the central role played by Chinese expatriates from Hong Kong, Taiwan, Europe, and the US as "market-makers" and

\footnotetext{
${ }^{33}$ Indeed over $50 \%$ of the world's 3.6 million outdated shuttle looms are in India.
} 
investors in new factories within China, as well as key links to new markets abroad (Chandra 1998). In this regard, Chinese firms and the government have also made significant organizational changes in the textile industry. First, China has improved the quality of the textile sector's supply chain management by revamping input supply and raw-material quality at one end, and investing heavily in improving the quality of finishing and dyeing processes at the other end. At least in the export sector, the Chinese government has also invested in developing new and improved yarn varieties, and helped firms adopt improved measurement and control systems that operate throughout the production chain, and limit wastage by helping detect defects. This is just the area where Indian industry is weakest. Several analysts have found that the absence of good quality finishing and dyeing, and poor quality or defective yarn, are key factors that limit the entry of Indian textile firms into higher-end markets (Belliti 1998, Chandra 1998).

Organizational change has also occurred at the inter-firm level in the Chinese textile industry. For example, as we noted above, Chinese exporters have reorganized production to improve delivery times, speed up the flow of information and products between producers and suppliers, and hence cut down on the need for in-process and input inventories. In 1998, according to one study, only 11 percent of textile firms in China held 75 days worth of raw-material inventories, compared to over 36 percent of Indian firms. These inventories have fallen much lower in recent years, even as time to market has improved greatly (Chandra 1998, Berger, Gartner and Karty 1997)

The Chinese government's efforts to combine technological change with organizational change and to not view technical upgrading as an end in itself, but as a means to market growth, illustrates a crucial, larger point that there are limits to relying exclusively on technological upgrading as a means of improving firm-competitiveness. (For example, involving new equipment, better plant infrastructure, improved transport, handling, storage, logistics, and process control mechanisms), the most impressive productivity gains have come from process improvements, and adopting new organizational practices, in addition to or along-side new capital investments. 
Indian firms, by contrast, have often pursed technology for technology's sake, and the way in which the government's modernization programs are designed, reinforces this bias. A recent study of machinery-use by engineering firms in five countries--India, China, Thailand, Korea, and the US--sponsored by the German Machine Tools found that in India most managers interviewed said productivity increases needed state of the art technology. Chinese firms, by contrast, were interested only in that level of technology that would help them secure wider access to markets abroad. They emphasized market access as the primary goal of production reform, and viewed new machinery and equipment in that light: as only one of many elements in a strategy that would help them increase their market share at both high and low ends of the product market (Meil, ISF, 1998).

The Chinese government is similarly strategic. In the textile industry case, the government did two things to strengthen the textiles production chain where it was weakest. First, it removed uncertainty around the access that firms had to raw materials by establishing new procurement arrangements. For example, the government set up institutions to channel raw materials and finished goods through regional pools. This pooled arrangement not only removed the uncertainty that firms had experienced around the availability of good quality domestic and imported raw materials; But in taking advantages of the scale economies that regional pooling offered, the government also lowered the cost to firms of imports and marketing. Second, the government improved the coordination across the production chain by making a single authority responsible for all permits, sales, and export formalities. A single apex body for each sub-sector handles all export formalities and coordinates across all the related sub-sectors in the production chain.

The government moreover, demanded reciprocity and maintained the capacity to discipline firms. In return for its support to the Textile Industry, the Chinese government demanded improved output and productivity from firms (especially exporters) and has instituted built-in disciplinary mechanisms to enhance compliance and firm performance. For example, wage increases--indeed wage bills-- for all Public Sector Units (PSUs) are 
tied to output levels, and benefits are linked to productivity increases. Managers of PSU are part of a "responsibility" system where they retain a share of their export revenues beyond a threshold of performance (Walder 1995 cf. Chandra 1998). Because each PSU must furnish its own foreign exchange to buy new equipment or carry out other restructuring, this incentive of retaining a part of their export earnings has driven many firms to export. Exports, clearly, are a key way for firms to earn revenues to purchase new technology and pay for process-oriented changes that help firms improve productivity, which in turn helps them win other support from the government. The government has also encouraged a "market" for innovation; and innovators periodically get together and sell their innovations to firms (Chandra 1998).

A related collaborative function between firms, workers and government agencies is the provision of adequate and modernized training to industrial workers and firm managers. The Chinese government has focused heavily on providing strong support for technical training as well as educational programs related to the textiles industry. Chinese firms, in turn, have also invested heavily in training their workforce in modern technology and management skills. For example, even seven years ago, a Chinese firm, on average, provided about 70 hours of training per year to its workers and managers compared to only ten hours in India. (Chandra 1998). China's advantages in textiles and apparel, beyond its low production costs, have been actively shaped by government policy and public action. Even as scale economies proliferate, a new more value adding, variable and flexible production system is simultaneously taking root.

\section{Section 6: Conclusions}

This paper reviewed the ongoing debate about the effects of quota removal on the competitiveness of apparel and textile firms, and the fortunes of supplier countries after the removal of global quotas. There is deep anxiety among many firms and supplier countries about their ability to hold their place in the global division of labor in textiles and apparel post-MFA given powerful trends toward consolidation of retailer networks and the widely anticipated shift of market share (and market power) towards Chinese 
textile and apparel exporters. The standard models on the effects of quota removal predict stark shifts of market share toward large, formerly constrained apparel suppliers such as China and secondarily India and countries like Mexico. Most of these models are based on traditional variables of competitiveness and trade - cost-competitiveness, price, technical change, tariffs, exchange rates, and scale -- the ability of producers to harness economies of scale and scope to meet the demands of rapidly consolidating global buyers.

The motivation for the review was to pull together arguments that have recently been made in the institutional literature that links industrial organization and global trade in textiles to caution against the notion that cost, scale and relative prices are the only metrics of global competitiveness in the textiles and apparel industry post-MFA. The paper reviewed arguments and evidence to make several points. First, that under the volatile market conditions that prevail today, it is not only price or cost competitiveness that matters, but the ability of firms for ongoing adjustment (Sabel and Reddy 2002). Second, that the changed market conditions make many more demands on firms (and exporters) in addition to price. Under conditions of intensified global competition, short product cycles and fragmented demand, buyers demand flexibility, good quality, variety, consistency and timeliness in addition to price.

In response to these demands firms have developed strategies that can be classified as 'low road' or 'high road.' Though portrayed dichotomously, these distinctions nevertheless capture paths to development and export competitiveness that focus primarily on low wages (low road) versus those that embody a new class of higher performance work practices that combine progressive labor practices, innovation, human capital development, technical progress and organizational flexibility.

We saw how, on the one hand, the rise of regional trade agreements, new demands of 'Lean Retailing,' (low inventories, rapid, short-cycle replenishment of fastmoving items, and the privileging of proximity for the sourcing of such items) and the growing power of global retailers in organizing trade and sourcing networks and 
managing far-flung clothing value chains has made trade "sticky" - in that the removal of quotas does not mean trade is "free" or that the most cost-efficient supplier will automatically win out. Embedded buyer-seller relationships, and the differential ability of suppliers to meet the several other, non-price criteria that buyers demand will be equally, if not more critical in shaping the new geography of textile and apparel production, sourcing and supply post-MFA. On the other hand, we saw how agency - the role of the government, support institutions and inter-firm relations - is key even in cases where cost and volume seem to supposedly dominate, such as in China.

The broad lessons of the evidence reviewed in this paper are that in a rapidly changing productive environment, and in an industry as footloose as apparel, a strategy that focuses on low wages as the sole or primary source of advantage is chimeric and seriously short-sighted. As some of the authors reviewed in the paper have pointed out (Berger, Gartner and Karty 1997, Piore 2002, Sabel and Reddy 2002, Tendler 2005), the deep vulnerability of this system of production comes from three sources: First, a low wage strategy lasts only as long as the next low wage site comes along. It leaves a country or a region with no special advantage that can cause investment and exports and the ensuring linkages to "stick" locally because there are scores of countries and regions that can organize production on the basis of cheap labor, low skills and mass volumes in ways that will generate goods that can be sold in low end markets of affluent countries, in the domestic market, or among peer nations. But it is in these segments that price competition is the most fierce, with continuous pressures to cut costs, erode wages, living conditions and ultimately, the sustainability (or developmental capacity) of such a model. Second, a low wage, low road model distances just those resources, conditions and opportunities that producers need to upgrade their capacities, products and production processes. Unable to absorb the tremendous potential in new, high productive, innovative work practices as well as technologies, such an approach pushes regions to an inexorable race to the bottom. This is mirrored in the dead-end development strategies that the low road leads us to - based as it is on attracting orders, or buyers, or FDI by offering cost advantages on the basis of low wages, dismantled labor laws, tax-incentives, cheap land and natural resources (Piore 2002). This downward spiral of zero-sum 
giveaways not only denudes local resources and capabilities, but ever so often leaves regions biting the dust when even 'better,' lower-cost incentives are offered by the next region, or state or country.

Finally, even when caught in a low-wage, low road trap, prices, land values, even wages rise, limiting the gains that can be squeezed out of such a system (Berger and Lester 1997). Without embracing the technological advances that are underway, building up the human capital and the skills that can use these technologies to generate innovations and productivity gains, which translate into high value products, access to new markets and production processes and better returns as well as, in turn, better working and living conditions, the global and national competitiveness of industrial work, especially in textiles and apparel, is likely to remain incomplete and unrealized.

As the evidence reviewed in this paper points out, ample opportunities exist for communities, countries and firms to build a more lasting competitive advantage that is based on the creation of deeper capabilities. These capabilities involve creativity in production, skill formation, technological innovation, $\mathrm{R} \& \mathrm{D}$, and innovations in marketing and distribution, along with the creation of support institutions that will help nurture the high road, allowing firms and workers to continually adapt to volatile markets. Such capabilities are founded on and in turn create locally-rooted capacities and interdependencies among firms, workers and suppliers that can generate unique advantages (Piore 2002, Tendler 2001) that "stick" in place, and grow and change in response to the demands of a dynamic competitive environment. Under such conditions costs and scale are not dichotomous to niches and small batches, but complementary parts of a broad-based process of development and innovation. 


\section{References}

Amsden, Alice. 1989. The Next Asian Giant. Oxford: Oxford University Press.

Appelbaum, Richard. 2005. "The Emergence of Giant Transnational Contractors in East Asia: Emergent Trends in Global Supply Chains." Mimeo, University of California at Santa Barbara.

Appelbaum, Richard. 2005. "The End of Apparel Quotas: A Faster Race to the Bottom?" Global and International Studies Program, University of California, Santa Barbara.

Bair, Jennifer, 2005. "From Commodity Chains to Value Chains and Back Again?" Mimeo, Yale University, Department of Sociology.

Bair Jennifer and Gary Gereffi, 2003. "Upgrading, uneven development and jobs in the North American apparel industry." Global Networks 3 (2): 143-169.

Bair, Jennifer and G. Gereffi. 2001. "Local Clusters in Global Chains: The Causes and Consequences of Export Dynamism in Toerreon's Blue Jeans Industry," World Development 29 (11): 1885-1903.

Begg, Bob, John Pickles and Adrian Smith, 2003. "Cutting it: European integration, trade regime, and the reconfiguration of East-Central European apparel production," Environment and Planning A, Vol 23:2191-2207

Berger, Suzanne, David Gartner, and Kevin, Karty. 1997. "Textiles and Clothing in Hong Kong." Chapter 9 in: Made by Hong Kong, ed., Suzanne Berger and Richard Lester. Hong Kong: Oxford University Press.

Berger, Suzanne, and Richard Lester (eds.). 1997. Made By Hong Kong. Hong Kong: Oxford University Press.

Best, Michael. 1990. The New Competition: Institutions of Industrial Restructuring. Harvard University Press: Cambridge, MA

Belliti, Carlo. 1997. "Analysis of three Indian textile clusters: Jaipur, Ludhiana, Tirupur.” Report to UNIDO's Small and Medium Enterprises Branch, Vienna.

Brusco, Sebastian. 1982. "The Emilian Model: Productive decentralization and social integration," Cambridge Journal of Economics, 6:167-184

Chandler, Alfred D. 1977. The Visible Hand: The Managerial Revolution in American Business. Cambridge, MA: Belknap/Harvard University Press.

Chandler, Alfred D. 1990. Scale and Scope: The Dynamics of Industrial Capitalism. Cambridge: Belknap/Harvard University Press. 
Chandra, Pankaj 1998. "Competing through Capabilities. Strategies for Global Competitiveness of Indian Textile Industry." Economic and Political Weekly Vol. XXXIV, No. 9. February 27, Pp. M-17-M-24.

Chatterjee, Chandrima. 2005. Presentation on Indian Textiles, Post-MFA, Jawaharlal Nehru University, New Delhi, February 2005.

Cole, Robert E. 1980. "Learning from the Japanese: Prospects and Pitfalls." Management Review 69 (Sept):22-42.

Collins, Jane. 2003. Threads. Gender, Labor and Power in the Global Apparel Industy. Chicago: Chicago University Press.

Commission of the European Communities, 2004. "Proposal for a Council Regulation amending Council Regulation (EEC) no.3030/93 and EC no. 3285/94 as regards the common rules for imports of certain textile products from third countries," CEC, Brussels, October 25.

Daio, X. and A. Somawaru 2001 "Impact of MFA Phase-out on the World Economy: an Intertemporal, Global General Equilibrium Analysis." TMD Discussion Paper No. 79, International Food Policy Research Institute, Washington D.C.

Dertousoz, M, R. Lester and R. Solow 1988. Made in America: Regaining the Competitive Edge. Cambridge, MA: MIT Press.

Dicken, Peter. 1990. Global Shift. Reshaping the Global Economic Map in the $21^{\text {st }}$ Century. New York and London: Guilford Press.

Dolan, Catherine 2004. "On Farm and Packhouse: Employment at the Bottom of a Global Value Chain.” Rural Sociology 69(1):99-126.

Dolan, Catherine and Meenu Tewari. 2001. "From What we Wear to What we Eat: Upgrading in Global Value Chains" IDS Bulletin 32(3):94-104.

Dussel, E., C. Ruiz-Duran, and M. Piore. 1996. "Adjustments in Mexican industries to the opening of the economy to trade." Massachusetts Institute of Technology, Cambridge and the Universidad Nacional Autonoma de Mexico, Mexico City

Elbehri, Aziz, Thomas Hertel and Will Martin. 2003. "Estimating the impact of WTO and Domestic Reforms on the Indian Cotton Industry." Review of Development Economics 7(3): 343-359.

Evans, Carolyn and James Harrigan 2005. "Distance, Time and Specialization: Lean Retailing in General Equilibrium" American Economic Review 95(1):292-313. 
Feenstra, R.C., 1998. "Integration of Trade and Disintegration of Production in the Global Economy," Journal of Economic Perspectives, 12 (4):31-50

Freeman, Richard. 2005. Presentation at the conference "End of global textile quotas: The new shape of the global economy," Harvard University, May 23-24, 2005.

Freeman, Richard. 2004. "Doubling the global workforce: The challenge of integrating China, India and the former Soviet bloc into the world economy." Presentation, Harvard University and NBER, Center for Economic Performance, London School of Economics.

Gereffi, Gary, John Humphrey and Timothy Sturgeon 2005. "The Governance of Global Value Chains," Review of International Political Economy 12(1):78-104

Gereffi, Gary, 2004. Industrial adjustment in the North Carolina Textile and Clothing Industry, Presentation at the Global Apparel/Clothing Europe Conference at the University of North Carolina at Chapel Hill, October 15-16, 2004.

Gereffi, Gary and Olga Memedovic. 2003. The Global Apparel Value Chain: What Prospects for Upgrading by Developing Countries? Report prepared for UNIDO, Vienna.

Gereffi, Gary, D. Spenner and J. Bair (eds.) 2002. Free Trade and Uneven Development: The North American Apparel Industry after NAFTA. Philadelphia: Temple University Press.

Gereffi, Gary and R. Kaplinsky (eds), 2001. Special Issue on The Value of Value Chains, IDS Bulletin Vol 32, No. 3. Sussex.

Gereffi, Gary, 1999. "International Trade and industrial upgrading in the apparel commodity chain," Journal of International Economics 48(1):37-70.

Gereffi, Gary and Mei-Lin Pan 1994. "The globalization of Taiwan's Garment Industry," In Global Production: The Apparel Industry in the Pacific Rim, eds., Edna Bonacich, Lucie chheng, Norma Chinchilla, Nora Hamilton, and Paul Ong. Philadelphia: Temple University Press.

Gereffi Gary and Michael Korzeniewic, 1994 Commodity Chains and Global Capitalism, Greenwoood: Connecticut, RI.

Gereffi, Gary, 1994. "The Organization of Buyer-driven Global Commodity Chains: How US Retailers Shape Overseas Production Networks." In Commodity Chains and Global Capitalism, eds, Gary Gereff and Michael Korzeniewic. Connecticut, RI: Greenwood Press.

Gherzi Report 2003. Benchmarking of Costs of Production of Textile Products in India visà-vis China, Pakistan, Indonesia, Bangladesh and Sri Lanka, Swiss Textile Organization. 
Gibbon, Peter. 2001. "Upgrading Primary Production: A Global Commodity Chain Approach." World Development 29(2): 345-363.

Gibbon, Peter, 2005. "Governance, entry barriers, upgrading. Re-interpretation of some GVC concepts from the experience of African garment exports." Mimeo. Danish Institute for International Studies. Paper presented at the conference on 'Global Production Networks,' Yale University, May 2005.

Granovetter, Mark. 1985. "Economic Action and Social Structure: The Problem of Embeddedness." American Journal of Sociology 91:481-510.

Grossman, Sanford, and Oliver Hart. 1983. "Implicit Contracts Under Asymmetric Information." The Quarterly Journal of Economics_98:123-156.

Hart, Oliver. 1989. An Economist's Perspective on the theory of the Firm." Columbia Law Review 89:1757-1774. November.

Hart, Oliver, and John Moore. 1988. "Property Rights and the Nature of the Firm," Working Paper No. 495. Department of Economics, MIT, Cambridge.

Hart, Oliver, and Bengt Holmstrom. 1987. "The Theory of Contracts. "In: Advances in Economic Theory, ed., Truman F. Bewley. Cambridge: Cambridge University Press.

Hashim, Danish, 2005. "Making the Textile Industry competitive after MFA," Economic and Political Weekly, Vol. XL No. 2, January 8-14, p. 117-127.

Hanson, Kenneth. and Kenneth A. Reinert 1997. "The Distributional Effects of U.S. Textile and Apparel Protection.." International Economic Journal 11(3):1-12

Harrisson, G.W., T. Rutherford and D.G. Tarr 1997. "Quantifying the Uruguay Round." Economic Journal 107: 1405-1430.

Herrigel, Gary 2004. "Emerging Stategies and Forms of Governance in High-Wage Component Manufacturing Regions.” Industry and Innovation March-June 2004:

Himmatsingka Seide. 2005. Interveiw and Company documents, mimeos. Bangalore

Hopkins, Terrance and Immanuel Wallerstein. 1986. "Commodity Chains in the World Economy Prior to 1800." Review 10:157-70 and "Commodity Chains: Construct and Research" Chapter 2 in Gereffi and Korzeniewiscz (eds.) Commodity Chains and Global Capitalism. Wesport: Glenwood Press. Pp. 17-20.

Humphrey, John and Hubert Schmitz, 2002. "How Does Insertion in Global Value Chains Affect Upgrading in Industrial Clusters?” Regional Studies 36(9):1017-1027. 
Johansson, Jan, and Lars-Gunnar Mattsson. 1987. "Inter-organizational Relations in Industrial Systems: A Network Approach Compared with the Transactions Cost Approach." International Studies of Management and Organization 17:34-48.

Kathuria, Sanjay, Will Martin and Anjali Bharadwaj, 2001. Export Quotas and Policy Constriants in the Indian Textile and Garment Industries, World Bank, Washington D.C.

Knappe, Matthias, 2003 “Textiles and clothing: what happens after 2005?" International Trade Forum, Issue 2/2003, International Trade Center, page 16, http://www.tradeforum.org/news/fullstory.php/aid/550/Textiles_and_Clothing:_What_Happens_After_200 $\underline{5 . h t m l}$

Lichtensein, Nelson. 2005. Walmart: A Template for $21^{\text {st }}$ Century Capitalism. New York: New Press (Forthcoming.)

Kathuria, Sanjay and Anjali Bhardwaj 1998. "Export Quotas and Policy Constraints in the Indian Textile and Garment Industries." Policy Research Working Paper No. 2012. Washington D.C. The World Bank.

Krishna, Kala, and Ling Hui Tan 1998. Rags and Riches: Implementing Apparel Quotas under the Multi-Fibre Arrangement. Ann Arbor: University of Michigan Press.

Krishna, Kala, R. Erzan and L. Tan. 1994. "Rent Sharing in the Multi-Fibre Arrangement: Theory and Evidence from US Apparel Imports from Hong Kong." Review of International Economics 2(1):62-73.

Levinsohn, Jim and Wendy Petropolous 2001. "Creative Destruction or Just Plain Destruction? The U.S. Textile and Apparel Industries Since 1972" NBER Working Paper No. 8348, Cambridge MA.

Lowe, Nichola. 2003. Trainers by Design: A Case Study of Inter-Firm Learning, Institution Building and Local Governance in Western Mexico. Unpublished Doctoral Dissertation, Department of Urban Studies and Planning, MIT, Cambridge, MA.

Loveman, Gary and O'Connell, Jamie 1996. Li \& Fung (Trading) Ltd. Harvard Business School Case Program. 9-396-075.

Nordås, Hildegunn Kyvik (WTO). 2004. "The Global Textile and Clothing Industry post the Agreement on Textiles and Clothing." Discussion No. 15, World Trade Organization, Geneva, Switzerland.

OECD. 2003. Liberalizing trade in textiles and clothing: A Survey of Quantitative Studies. Working Party of the Trade Committee. TD/TC/WP(2003)2/Final, Organization of Economic Co-operation and Development. France.

Kreps, David M., and Robert Wilson. 1982. "Reputation and Imperfect Information. Journal of Economic Theory 27:253-279. 
Meil, Pamela. 1998. Personal communication regarding ISF's study on the engineering and machine tool sectors in India, China, South Korea, Thailand, and the United States. Institute für Sozialwissenschaftliche Forschung (ISF), Munich, Germany.

Pfeffer, Jeffrey, and James Baron. 1988. "Taking the Workers Back Out: Recent Trends in the Structuring of Employment." Research in Organizational Behavior 10:257-303.

Reinert, K. A. 1993. "Textile and Apparel Protection in the United States: A General Equilibrium Model” World Economy 16:359-376.

Rosenberg, Michael H. 2005. "Dreams, Denim and Destiny: Competitive Responses in the Blue Jeans Maquiladoras of Mexico's La Laguna Region..” Unpuplished Thesis, Harvard University.

Piore, Michael. 2002. "The Reconfiguration of Work and Employment Relations in the United States at the Turn of the Century." Mimeo, Massachusetts Institute of Technology, Cambridge MA.

Piore, Michael and Charles Sabel. 1984. The Second Industrial Divide. New York: Basic Books.

Palpeceur F., et. al., 2005. "New challenges for developing country suppliers in global clothing chains: A comparative European perspective" World Development (In press).

Pickles, John, 2002. "Gulag Europe? Mass Unemployment, New Firm Creation, and Tight Labor Markets in the Bulgarian Apparel Industry." Pp 246-272 in Work, Employment, and Transition: Restructuring Livelihoods in Post-Communism. Ed. A. Rainnie, A. Smith, and A. Swain. London: Routledge.

Porter, Michael 1990. The competitive Advantage of Nations. New York: Free Press.

Powell, Walter 1990. "Neither market nor hierarchy: network forms of organization," Research in Organzational Behavior 12:295-336.

Sabel, 1989. "Flexible specialization and the reemergence of regional economies. "In P. Hirst and J. Zeitlin (eds.) Reversing Industrial Decline? St. Martin's Press: New York. Pp. 17-70.

Singhal, A., S. Sood, and V. Singh. 2004. "Creating and Preserving Value in the Textile and Apparel Supply Chain: From Fibre to Retail," Textile Outlook International, JanuaryFebruary. Pp. 135-156.

Sabel, Charles and Sanjay Reddy. 2002. "Learning to Learn: Undoing the Gordian Knot of Development Today." Mimeo, Columbia University. 
Schmitz, Hubert, 1999. "Global Competition and Local Cooperation: Success and Failure in the Sinos Valley, Brazil," World Development 27(9): 1627-1650

Schmitz, Hubert (ed). 2004. Local Enterprises in the Global Economy: Issues of Governance and Upgrading. Edward Elger: Cheltenham.

Seller, Christian, 2005. Mimeo. University of North Carolina at Chapel Hill.

Smith, Adrian, et. al. 2004. "Upgrading the East European Apparel Industry: Outsourcing and the 'Embedded Geographies' of Production," Paper presented at the conference, "Clothing Europe: Comparative Perspectives on Trade Liberalization and Production Networks in the New European Clothing Industry," University of North Carolina at Chapel Hill, NC October 15-16.

Taplin, Ian. 1994. "Strategic reorientation of US apparel firms." In: G. Gereffi and M. Korezeneiwicz, (eds.) Commodity Chains and Global Capitalism. Greenwood Press, Wesport CT and London.

Tendler, J. 2000. "The Economic Wars Between the States." Working Paper, MIT, Cambridge, MA.

Tendler, J. 2001, "Transforming Local Economies: Lessons from Northeast Brazilian Experience.” MIT, Bank of Northeast Brazil Research Project.

Tendler, J. 2001. "Comments on the paper "Governance and Upgrading." for the Workshop 'Local Upgrading of Global Chains," Institute of Development Studies at the University of Sussex, UK.

Tendler, J. 2005. "Undoing the poverty agenda and putting it back together: social policy, economic development, or what?" Forthcoming in Reinventing Foreign Aid, ed. William Easterly, MIT Press, Cambridge.

Tewari, M. 2005. "Post-MFA adjustments in India's textile and apparel industry: emerging issues and trends," ICRIER Working Paper No. 167. Indian Council for Research on International Economic Relations, New Delhi.

Thun, Eric 2000. "Growing Up and Moving Out: Globalization in the Taiwanese Textile/Apparel and Automotive Sectors.” MIT IPC Working Paper \#00-007, June.

Thorelli, H. 1986. "Networks: between Markets and Hierarchies, "Strategic Management Journal 7: 37-51

UNCTAD. 2005. TNCs and the Removal of Textiles and Clothing Quotas. Current Studies in FDI and Development, UNCTAD, New York and Geneva. 
US ITC, 2004. Textiles and Apparel: Assessment of the Competitiveness of Certain Foreign Suppliers to the US Market, Washington D.C., Report declassified in January 2004.

Verma, Samar. 2002. "Export Competitiveness of the Indian Textile and Garment Industry," Working Paper No. 94, ICRIER, Indian Council for Research on International Economic Relations New Delhi.

Williamson, O.E. 1975. Markets and Hierarchies. Free Press: New York.

Williamson, O.E. 1985. The Economic Institutions of Capitalism: Firms, Markets and Relational Contracting. Macmillan: London.

Yang, Y. W. Martin and K. Yanagishima 1997. "Evaluating the Benefits of Abolishing the MFA in the Uruguay Round Package." In Global Trade Analysis: Modeling and Applications, ed. T. Hertel, Cambridge, Cambridge University Press. 